\title{
Real-Time Monitoring of Climactic and Geotechnical Variables during Landslides on the Slopes of Serra do Mar and Serra da Mantiqueira (São Paulo State, Brazil)
}

\author{
Rodolfo Moreda Mendes', Mário Valério Filho² \\ ${ }^{1}$ National Center for Monitoring and Warning of Natural Disasters-CEMADEN, São José dos Campos, Brazil \\ ${ }^{2}$ IP \& D, Vale do Paraíba University, São José dos Campos, Brazil \\ Email: rodolfo.mendes@cemaden.gov.br, mvalerio@univap.br
}

Received 19 September 2014; accepted 24 March 2015; published 26 March 2015

Copyright (C) 2015 by authors and Scientific Research Publishing Inc.

This work is licensed under the Creative Commons Attribution International License (CC BY).

http://creativecommons.org/licenses/by/4.0/

c) (†) Open Access

\begin{abstract}
The municipalities of Ubatuba, Campos do Jordão, and São José dos Campos are located in the region of São Paulo State (Brazil). These municipalities are recognized nationally for having an elevated number of recorded landslides on slopes and embankments. In addition, these municipalities contain multiple areas that are at risk for landslides. Various soil landslides occurred in these municipalities in January 2013, when real-time climactic and geotechnical variables were monitored by automatic rain gauges, humidity sensors and soil temperature and suction devices. The resulting data were used to understand the functions of each variable in the occurrence of landslides. Analyses of rainfall, humidity and soil temperature were used with field investigations to formulate a hypothesis regarding the predominant rupture mechanism and the role of each monitored variable in the deflagration of the soil landslides that occurred in the three studied municipalities. The geotechnical variable data revealed that both temperature and soil moisture contents played fundamental roles in the deflagration of shallow planar landslides in urban areas. The hourly rain intensity and/or rainfall accumulation for 24 and/or $72 \mathrm{~h}$ were responsible for the deflagration of the landslides that occurred in the studied areas, along with the existing anthropic constraints in the risk areas. Significant variations did not occur in the soil suction data during the landslides, principally due to the unsatisfactory sensor precision when reading field suction between -10 and $-100 \mathrm{kPA}( \pm 25 \%)$.
\end{abstract}

\section{Keywords}

Landslides, Urban Area, Real-Time Monitoring, Analysis of Rainfall and Geotechnical Parameters 


\section{Introduction}

Geologic risks in São Paulo State (Brazil) have been highlighted nationally and internationally, mainly due to the elevated number of landslides that have occurred on urban slopes and the number of municipalities with areas of landslide risk. Several municipalities that are located in regions with elevated landslide susceptibility are notable [1]. For example, the municipalities with urban areas on the slopes of the Serra da Mantiqueira (Campos do Jordão and São José dos Campos) and Serra do Mar (Ubatuba). The susceptibility of these areas to landslides has been corroborated by the significant number of landslides that have been registered by the Geological Institute of São Paulo State (Figure 1) in the framework of the Preventative Plan of Civil Defense (PPDC).

The identification, evaluation and management of landslide risk areas in São Paulo State (Brazil) began following large scale accidents with grave consequences that occurred during the summer of 1987/1988 in the region of Serra do Mar. Consequently, the state government decided to implement the PPDC, which was specific for landslides on the slopes of the Serra do Mar in Sao Paulo State. The main objective of the PPDC is to avoid human death by relocating populations that occupy risk areas before a landslide occurs. However, to prevent death from landslides, the actions of the PPDC are based on the daily monitoring of critical rainfall levels (rain accumulated in $72 \mathrm{~h}$ ) and the meteorological forecasts for each municipality. The critical rainfall levels used in the preventative removal action of populations from risk areas were defined based on a correlative study between rainfall and landslides that was initially designed for the municipality of Cubatão, São Paulo State [2] [3].

The correlation results obtained in [2] [3] for the municipality of Cubatão were posteriorly extrapolated for the remaining municipalities of São Paulo State by using the 72-h accumulated rainfall data as a reference. With this method, different values of critical rain accumulation were established for the municipalities using the PPDC. These values highlighted the 72-h rainfall accumulations in the following regions: Serra do Mar (Ubatuba)—120 mm; Vale do Paraiba (São José dos Campos)—100 mm and Serra da Mantiqueira (Campos do Jordão)—80 mm.

A significant number of national and international studies were observed to establish correlations between

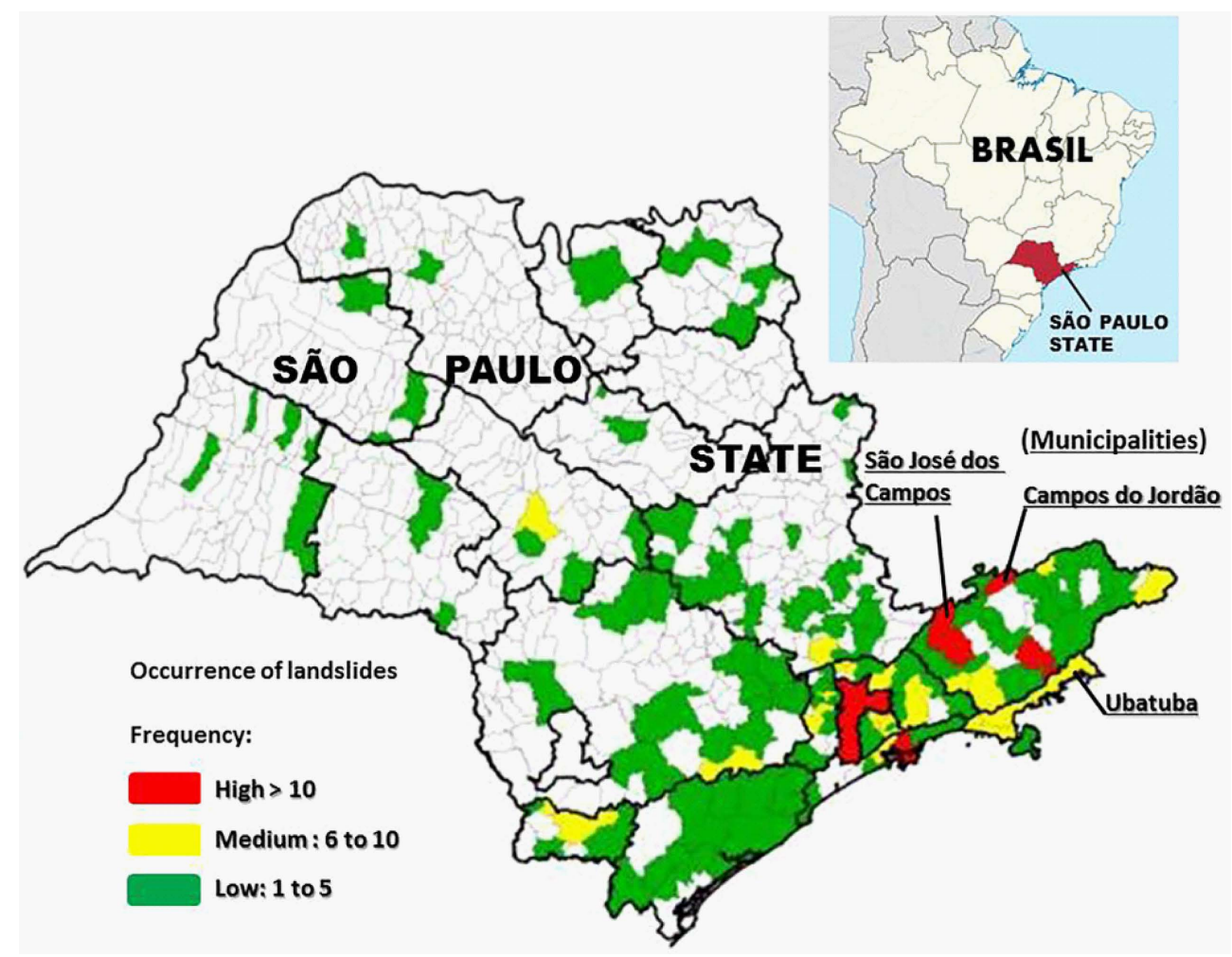

Figure 1. Spatial distribution of the occurrences of landslides in the municipalities of the São Paulo State in the period 2000 to 2010 (Source: Geological Institute). 
rainfall and gravitational mass movements. Among these international studies, developments in [4]-[20] are notable. In Brazil, the studies of [2] [3] [21]-[31] are noteworthy.

However, the spatial distribution of rainfall in a particular region is not homogeneous and tends to be less correlated with landslides when rain gauges are farther apart, especially when convective rainfall occurs in Brazil during the summer season, which generally has high spatial variability [32]. Therefore, the extrapolation of rainfall data points that represent a given area where landslides have occurred represents critical rainfall values in other regions that may contain inadmissible uncertainties for the operation of the PPDC. In addition, the critical rainfall rates used in certain areas cannot satisfactorily represent the critical rainfall conditions that are necessary for the deflagration of landslides in other regions that have different geological and geotechnical characteristics. This disconnect was recently observed by analyzing rainfall and landslide data within the PPDC that were recorded over 10 years [33]. Overall, this finding highlights the importance of monitoring parameters that are related to the geological and geotechnical characteristics of each region or risk area to understand the rupture mechanisms of landslides in urban areas, especially those parameters that permit infiltration and rainwater retention assessments.

Studies of climate and geotechnical variables on slopes in the Serra do Mar, specifically on the northern coast of São Paulo (Brazil), have been conducted by Brazilian researchers since 2005. These studies have contributed to understanding the effects of seasonal rainfall variations on the suction and humidity profiles of non-saturated residual soils [34]-[38]. Moreover, these studies have contributed to the use of sensors and non-invasive methods for assessing the suction profiles and moisture contents of tropical residual soils [38]-[43].

In Brazil, the climate and peculiar characteristics of tropical residual soils have generated the need for specific studies that combine climactic variables and soil geotechnical properties to understand the hydro-mechanical behavior of the soil and the relationships between climate and the geotechnical variables that trigger landslides in such soils.

Residual soil landslides are often associated with the rainy season on Brazilian slopes. According to [44], the main geotechnical variable for the occurrence of landslides is the reduction or elimination of shear soil strength that results from rainwater infiltration in the soil profile. For landslides in tropical residual soils, it is important to study the seasonal variations of matrix suction and moisture content within the soil profile that result from periods of rain and drought. Thus, it is important to evaluate the influence of rainfall on the hydro-mechanical behavior of the soil by monitoring climactic aspects and their effects on the matrix suction and moisture contents of the soil profile. Therefore, this paper presents new real-time monitoring results from geotechnical and climactic variables that are obtained by installing automatic rain gauges and sensors. These sensors measured total rainfall, suction, temperature and soil moisture in the municipalities of Campos do Jordão, São José dos Campos and Ubatuba, São Paulo State (Brazil), where several landslides occurred in risk areas during the in situ monitoring period.

\section{Study Areas}

\subsection{Selection and Location}

The initial criteria for selecting the study areas for implementing the field trials considered the following regional aspects of the physical and urban environment of each municipality: 1) distinct regional climate variations (in terms of rainfall distribution), 2) regional aspects of relief and 3) the presence of landslide risk areas. In addition, the following conditions were used to choose the study areas: 1) areas with high and/or very high risk levels for landslides, 2) areas with safe areas for equipment installation and monitoring and 3) areas with adequate mobile phone signal to enable data transmission via GSM/GPRS technology.

The selected study areas are located in municipalities with individual climate features that are based on regional climates and reliefs (according to Martinelli 2010: Faixa Costeira (Ubatuba), Porção Lestedo Planalto Atlântico (Campos do Jordão), and Vale do Paraíba (São José dos Campos). The locations of the experimental plots in the municipalities of Campos do Jordão (Ef-1), São José dos Campos (Ef-2) and Ubatuba (Ef-3) are shown in Figure 2.

Consequently, the regional climate and relief patterns for each municipality provide distinct average annual rainfall values. For example, Sera do Mar and Mantiqueira, where the municipalities of Ubatuba (Ef-3) and Campos do Jordão (Ef-1) are situated, have average annual rainfalls of between 1700 - $3000 \mathrm{~mm}$, respectively. In addition, the average rainfall in Vale do Paraíba, where the municipality of São José dos Campos (Ef-2) is si- 
tuated, is between 1200 and $1400 \mathrm{~mm}$ (Table 1).

\subsection{Geological and Geotechnical Characterization}

The geological and geotechnical characterization of each experimental region was initially performed in the field by observing the soil profiles that were considered the most critical (exhibiting greater natural susceptibility to landslides). These areas represented landslide risk areas (dashed yellow line) in the municipalities of Campos do Jordão (Ef-1), São José dos Campos (Ef-2) and Ubatuba (Ef-3) (Figure 3). Briefly, the following regional and local geological features of each experimental field were obtained:

$>$ Campos do Jordão (Ef-1)—Metamorphic rocks, such as migmatites, gneisses, metadioritic and granulites dominate the region. In addition, schists, quartzites and metaconglomerates occur as lenses with some magmatic intrusions [46]. Migmatitic rocks occur locally with alternating bands of neosome (granite) and paleosome (gneiss), with thicknesses that range from a few meters (in the case of granite) to centimeters (in the case of gneisses) thick [47] [48].

$>$ São José dos Campos (Ef-2)—The study area is regionally inserted into the tectonic compartment

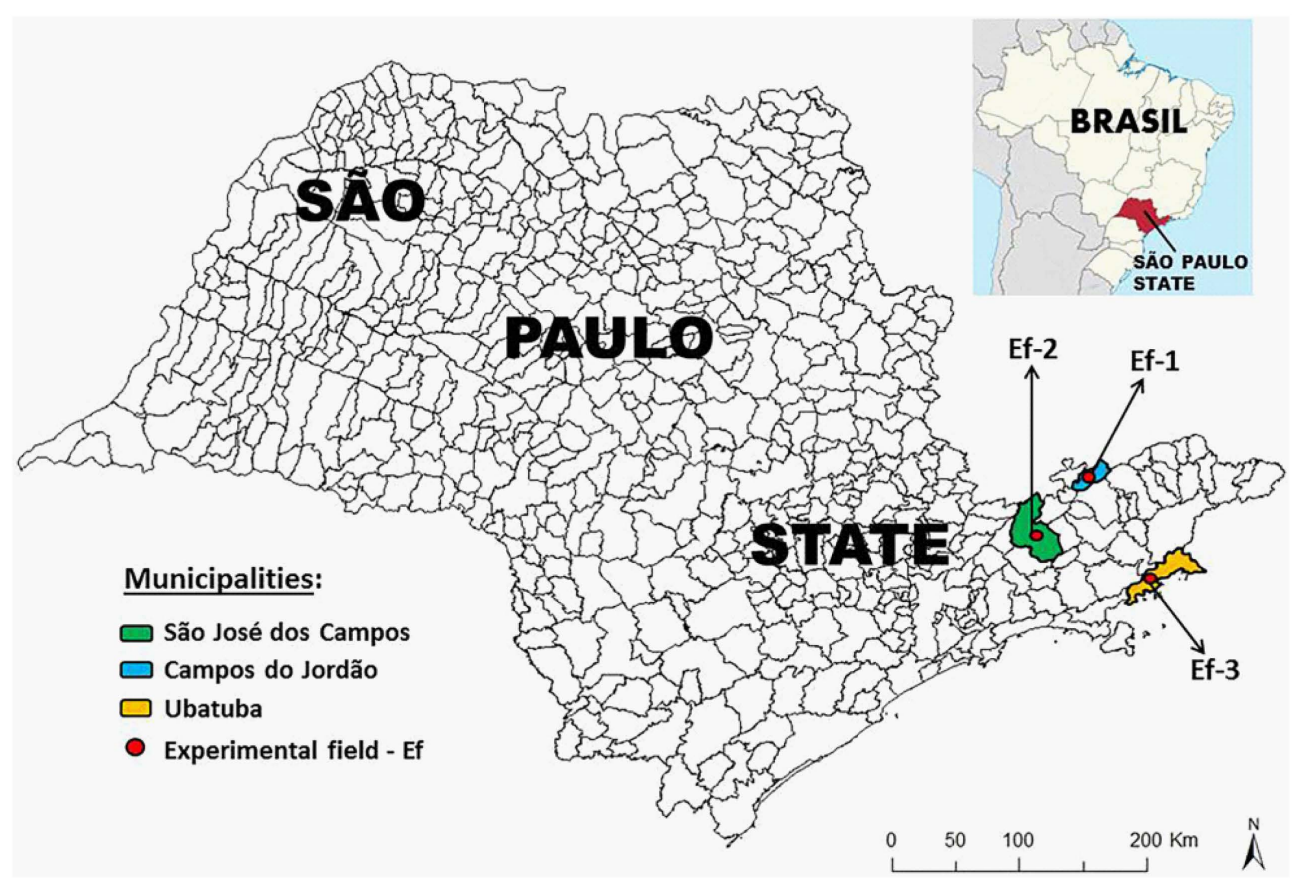

Figure 2. Localization of the municipalities in the São Paulo State (Campos do Jordão, São José dos Campos e Ubatuba) where were implanted the experimental fields (Ef-1, Ef-2 e Ef-3), respectively.

Table 1. Minimum, maximum and average rainfall annual values of the studied areas.

\begin{tabular}{|c|c|c|c|c|c|c|c|}
\hline \multirow{2}{*}{ Municipalities } & \multicolumn{3}{|c|}{ Rainfall average annual (mm) } & \multirow{2}{*}{$\begin{array}{l}\text { Period } \\
\text { (Year) }\end{array}$} & \multicolumn{2}{|c|}{ Rain gauge localization } & \multirow{2}{*}{$\begin{array}{l}\text { Altitude } \\
\text { (Meters) }\end{array}$} \\
\hline & Minimum & Maximum & Average & & Latitude & Longitude & \\
\hline \multirow{2}{*}{ São José dos Campos } & 917 & 2.055 & 1.289 & 1943 to 2003 & $23^{\circ} 11^{\prime} \mathrm{S}$ & $45^{\circ} 53^{\prime} \mathrm{W}$ & 560 \\
\hline & 887 & 2.271 & 1.396 & 1943 to 2000 & $23^{\circ} 03^{\prime} \mathrm{S}$ & $45^{\circ} 54^{\prime} \mathrm{W}$ & 570 \\
\hline \multirow{2}{*}{ Campos do Jordão } & 1.035 & 4.457 & 1.801 & 1937 to 2004 & $22^{\circ} 43^{\prime} \mathrm{S}$ & $45^{\circ} 34^{\prime} \mathrm{W}$ & 1590 \\
\hline & 1.342 & 2.786 & 1.778 & 1973 to 2001 & $22^{\circ} 42^{\prime} \mathrm{S}$ & $45^{\circ} 29^{\prime} \mathrm{W}$ & 1620 \\
\hline \multirow{2}{*}{ Ubatuba } & 1.777 & 4.374 & 3.057 & 1957 to 2004 & $23^{\circ} 23^{\prime} S$ & $45^{\circ} 07^{\prime} \mathrm{W}$ & 142 \\
\hline & 1.414 & 3.977 & 2.399 & 1945 to 2000 & $23^{\circ} 23^{\prime} \mathrm{S}$ & $44^{\circ} 50^{\prime} \mathrm{W}$ & 184 \\
\hline
\end{tabular}

The altitude is relative to sea level. Source of the data [45]. 

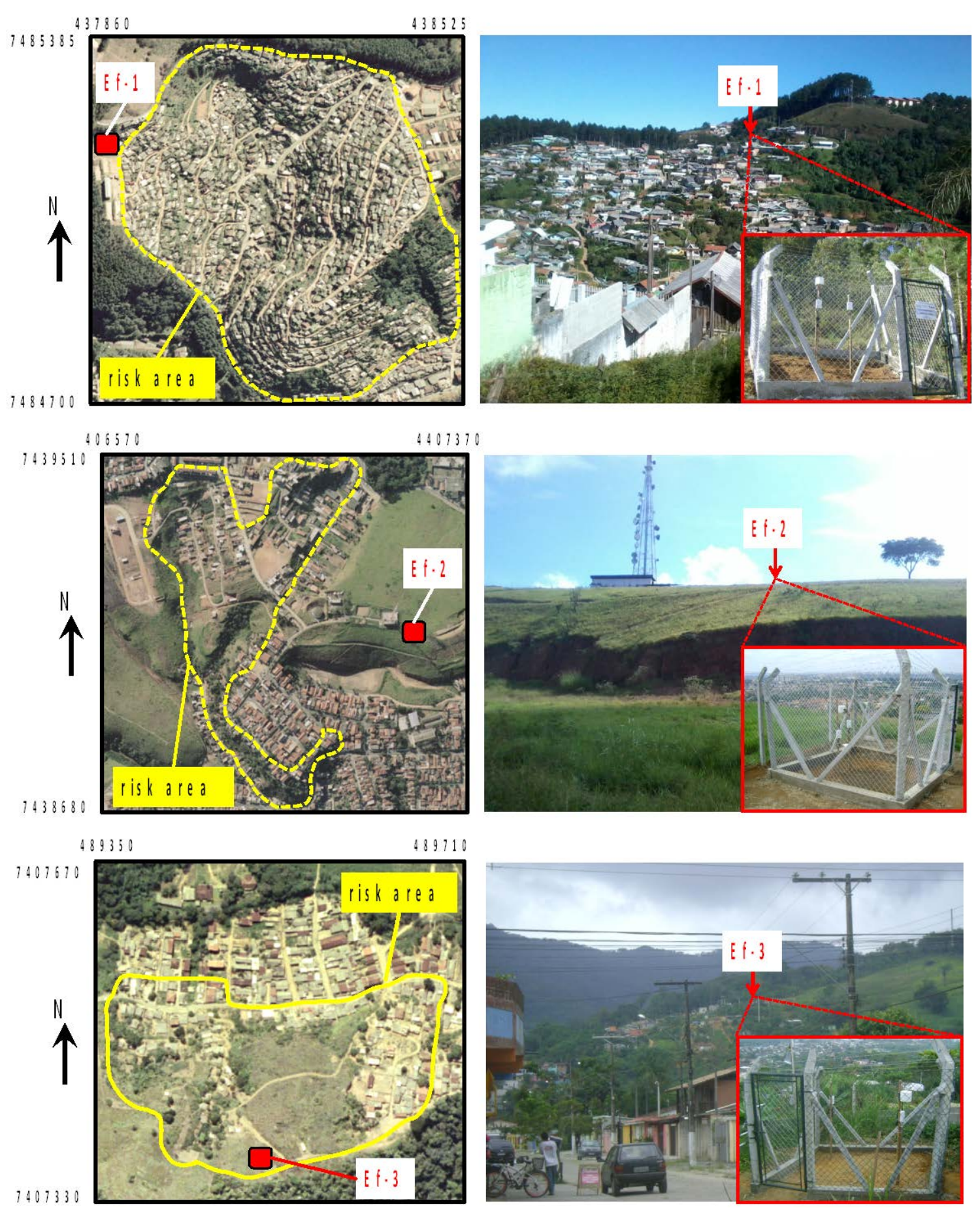

Figure 3. Localization of the experimental fields implanted in the landslides risk areas in the municipalities of Campos do Jordão (Ef-1), São José dos Campos (Ef-2) e Ubatuba (Ef-3).

named the Southeast Regional Fold with rocks of the Embu Complex (paragneiss units and banded gneiss) that are composed of phyllites, schists, gneisses and migmatites. Locally rocks consisting of gneisses and migmatites are dominant without the marked occurrence of lithological variations [49].

$>$ Ubatuba (Ef-3) - regionally occurring rocks grouped into five predominant lithologic assemblages of migmatites with diverse structures, granite-gneiss, biotite gneiss, quartzite and gneiss and gneisses changing to migmatite [50] [51]. Locally, rocks composed of porphyritic biotite granite and charnockites are not dominant. 
Geotechnical characterization began with the identification of representative soil profiles in the experimental fields Ef-1, Ef-2 and Ef-3. These profiles had the following soil horizons: 1) Horizon "H1", topsoil resulting from pedogenesis with a thickness of 0.7 to $1.0 \mathrm{~m}$; 2) Horizon "H2", the mature residual soil (no matrix rock structure and relatively homogeneous) with a thickness of 2.5 to $4.0 \mathrm{~m}$; and 3) Horizon "H3", young residual soil or saprolites resulting from a rocky basement with the original matrix rock structure and a thickness of 5 to $15 \mathrm{~m}$.

The thickness variations of the soil horizons were directly related to the position of the slope profile and its morphology, with greater depths at end regions and shallower portions at the bases of the slopes. The water table was considerably deeper on the slopes where experimental fields were planted and where upwelling or resurgences of water were not observed during field investigations. In Figure 4, schematic soil profiles of the three experimental fields are presented. These profiles were determined at the locations where the climactic and geotechnical monitoring systems were implemented.

After identifying the soil profiles of each experimental site, representative samples of each soil horizon (H1, $\mathrm{H} 2$ and H3) were collected for geotechnical characterization according to the Brazilian Technical Standards (ABNT). The geotechnical characterizations of sieve analysis, soil grain density, natural density and the Atterberg limits (liquid and plastic limits) were performed with deformed samples that were collected in the study sites of Campos do Jordão, São José dos Campos and Ubatuba. The overall results of the geotechnical characterization tests are shown in Table 2.

\subsection{Landslides Characteristics in the Study Areas}

Landslides in regions with the soils that often occur in the Serra do Mar and Serra da Mantiqueira (where the experimental sites are located) are usually associated with the rainy season [52]. Soil landslides, especially those of translational or planar shallow soils, occur naturally in middle and high slopes with rugged reliefs, even if the slopes are free of human influence.

The primary mechanism of slope destabilization is the reduction or elimination of "apparent" soil cohesion, which results from the infiltration of rainwater through the soil profile [22] [52] [53]. Because this type of destabilization is the dominant form of instability in the studied areas, it is important to monitor soil water infiltration and retention (rainfall, moisture content, suction and temperature) continuously to understand the function of each variable in this type of instability mechanism.
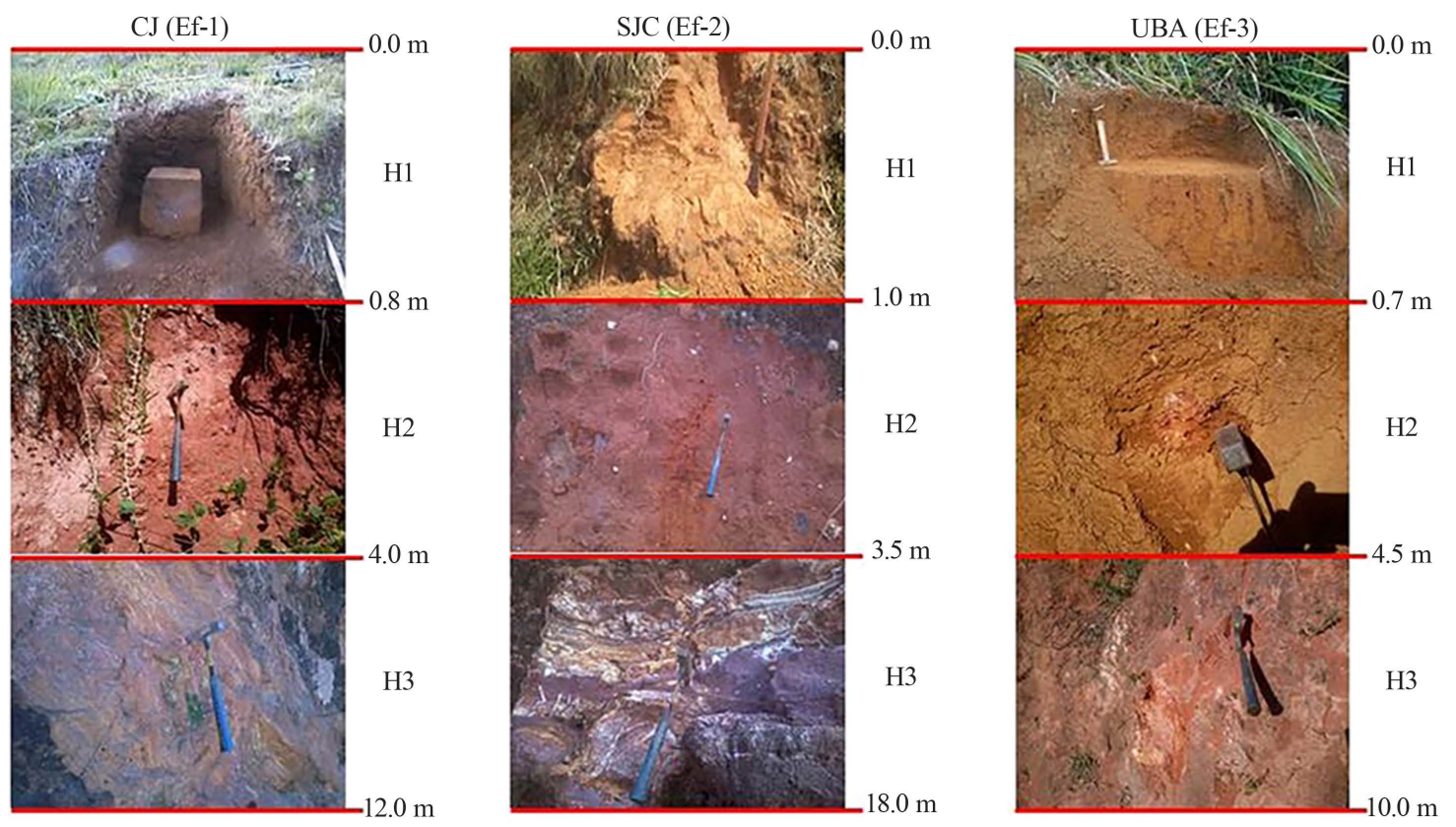

Figure 4. Soil profiles representative of the experimental fields of Campos do Jordão (Ef-1), São José dos Campos (Ef-2) e Ubatuba (Ef-3). 
Table 2. Geotechnical characterization of the Ef-1, Ef-2 and Ef-3 experimental field.

\begin{tabular}{|c|c|c|c|c|c|c|c|c|c|c|c|c|c|}
\hline \multirow{3}{*}{$\begin{array}{l}\text { Municipalities/ } \\
\text { experimental } \\
\text { field }\end{array}$} & \multirow{2}{*}{\multicolumn{2}{|c|}{ Localization }} & \multirow{3}{*}{$\begin{array}{l}\text { Sample/ } \\
\text { layer in } \\
\text { soil profile }\end{array}$} & \multirow{3}{*}{$\begin{array}{l}\text { Depth } \\
\text { sample } \\
\text { (m) }\end{array}$} & \multicolumn{3}{|c|}{ Grain size (\%) } & \multicolumn{3}{|c|}{ Atterberg limits } & \multirow{2}{*}{\multicolumn{2}{|c|}{$\gamma_{s}$}} & \multirow{3}{*}{$\begin{array}{c}\gamma \\
\left(\mathrm{kN} / \mathrm{m}^{3}\right)\end{array}$} \\
\hline & & & & & & & & $\mathrm{w}_{\mathrm{L}}$ & $\mathrm{W}_{\mathrm{p}}$ & IP & & & \\
\hline & Long. & Lat. & & & & & & (\%) & (\%) & $(\%)$ & USCS & $\left(\mathrm{kN} / \mathrm{m}^{3}\right)$ & \\
\hline \multirow{3}{*}{$\begin{array}{l}\text { Campos do } \\
\text { Jordão (Ef-1) }\end{array}$} & \multirow{3}{*}{$45^{\circ} 36^{\prime} \mathrm{W}$} & \multirow{3}{*}{$22^{\circ} 44^{\prime} \mathrm{S}$} & CJ-H1 & 0.3 & 54 & 19 & 27 & 25 & NP & NP & ML & 29.6 & 13.1 \\
\hline & & & CJ-H2 & 3.0 & 42 & 14 & 44 & 31 & 29 & 2 & ML & 23.5 & 16.2 \\
\hline & & & CJ-H3 & 6.0 & 67 & 26 & 7 & 24 & 21 & 3 & SM & 27.0 & 13.8 \\
\hline \multirow{3}{*}{$\begin{array}{l}\text { São José dos } \\
\text { Campos (Ef-2) }\end{array}$} & \multirow{3}{*}{$45^{\circ} 54^{\prime} \mathrm{W}$} & \multirow{3}{*}{$23^{\circ} 09^{\prime} \mathrm{S}$} & SJC-H1 & 0.5 & 56 & 18 & 26 & 29 & $\mathrm{NP}$ & $\mathrm{NP}$ & SM & 26.8 & 15.0 \\
\hline & & & SJC-H2 & 3.0 & 36 & 8 & 56 & 27 & 20 & 7 & CL-ML & 26.6 & 14.4 \\
\hline & & & SJC-H3 & 6.5 & 57 & 34 & 9 & 27 & 24 & 3 & SM & 26.9 & 15.7 \\
\hline \multirow{3}{*}{ Ubatuba (Ef-3) } & \multirow{3}{*}{$45^{\circ} 06^{\prime} \mathrm{W}$} & \multirow{3}{*}{$23^{\circ} 26^{\prime} \mathrm{S}$} & UBA-H1 & 0.4 & 53 & 16 & 31 & 50 & 37 & 13 & MH-ML & 27.1 & 17.4 \\
\hline & & & UBA-H2 & 1.5 & 41 & 13 & 46 & 48 & 23 & 25 & CL & 26.3 & 16.5 \\
\hline & & & UBA-H3 & 7.0 & 54 & 20 & 26 & 45 & 26 & 19 & CL & 26.7 & 15.2 \\
\hline
\end{tabular}

In general, the major natural constraints that are responsible for translational landslides in the study areas include high slope steepness (generally larger than $30^{\circ}$ ), which is associated with morphology (concave and/or linear geometry), and the presence of seasonal "apparent" cohesion, which results from an unsaturated soil profile and high rainfall (cumulative and/or hourly rainfall intensity). In addition, human action in these locations, such as slope cuts and/or dumped fills, overloading the land and the release of wastewater and/or leaking pipes on the slopes, significantly increases the geotechnical instability.

The landslides recorded in the Campos do Jordão (Ef-1) and São José dos Campos (Ef-2) study areas were planar or shallow translational (depth of rupture $<2.0 \mathrm{~m}$ ) and occurred in urban areas. In this case, the three (03) following predominant rupture mechanisms were observed (Figure 5): A—surface rupture in the layer of residual soil slope H1; B - surface rupture in the residual soil layer H2 or H1 cut slope; and C-surface rupture at the base of the created fill or at the slope of the residual soil layer of H1 (with mobilization of the overlying dumped fill). Generally, the type "C" rupture mechanism moves greater amounts of material, which reach a larger number of homes and cause serious damage. The failure mechanisms of landslides that occurred in the city of Campos do Jordão between 01/11/2013 and 01/13/2013 are presented in Figure 5 (A, B, or C). Figure 6 shows the locations of the eight (08) landslides that occurred in the city of Campos do Jordão near the experimental field (Ef-1) between 01/11/2013 and 01/13/2013 (blue dots). In addition, Figure 6 shows eighteen (18) landslides that were recorded in 2000 (red polygons on map).

Landslides that occurred in the city of São José dos Campos between 01/10/2013 and 01/11/2013 are presented in Figure 7. Figure 8 shows the locations of the two (02) landslides that occurred in the city of São José dos Campos near the experimental site (Ef-2) between 01/10/2013 and 01/11/2013 (blue dots). In addition, Fig. 8 shows the 61 landslides that were recorded between 2009 and 2013 (Figure 8, A).

The landslides that occurred near the experimental monitoring site of Campos do Jordão (Ef-1) and São José dos Campos (Ef-2) were affected by anthropic components, including instability factors. These factors included the implementation of slope cuts and dump fills, the discharge of wastewater and rainwater on slopes and/or slope cuts/landfills and the discharge of leaking pipes on slope or slope cuts/landfills. Consequently, rainfall, depending on its hourly intensity or total accumulation over 24,48 or $72 \mathrm{~h}$, was responsible for the outbreak of occasional landslides in these urban areas.

A landslide of soil and rock across a $14 \mathrm{~km}$ stretch of highway BR 101 is shown in Figure 9. This landslide occurred between January 3 and 4, 2013. Resurgences of water occurred in adjacent areas along the base of the slope based on the massive slow movement (crawling), the scattered erosion in the form of grooves and the presence of small to large blocks of rock at the base of the slope from the last event. This landslide process on the natural slope in the Serra do Mar was shallow planar and moved the residual soil layers of $\mathrm{H} 1$ and $\mathrm{H} 2$ at the top of the slope. The major predisposing factor of instability was the occurrence of the previous event, which removed a significant amount of material (soil and rock) at the base of the slope. This event was associated with 


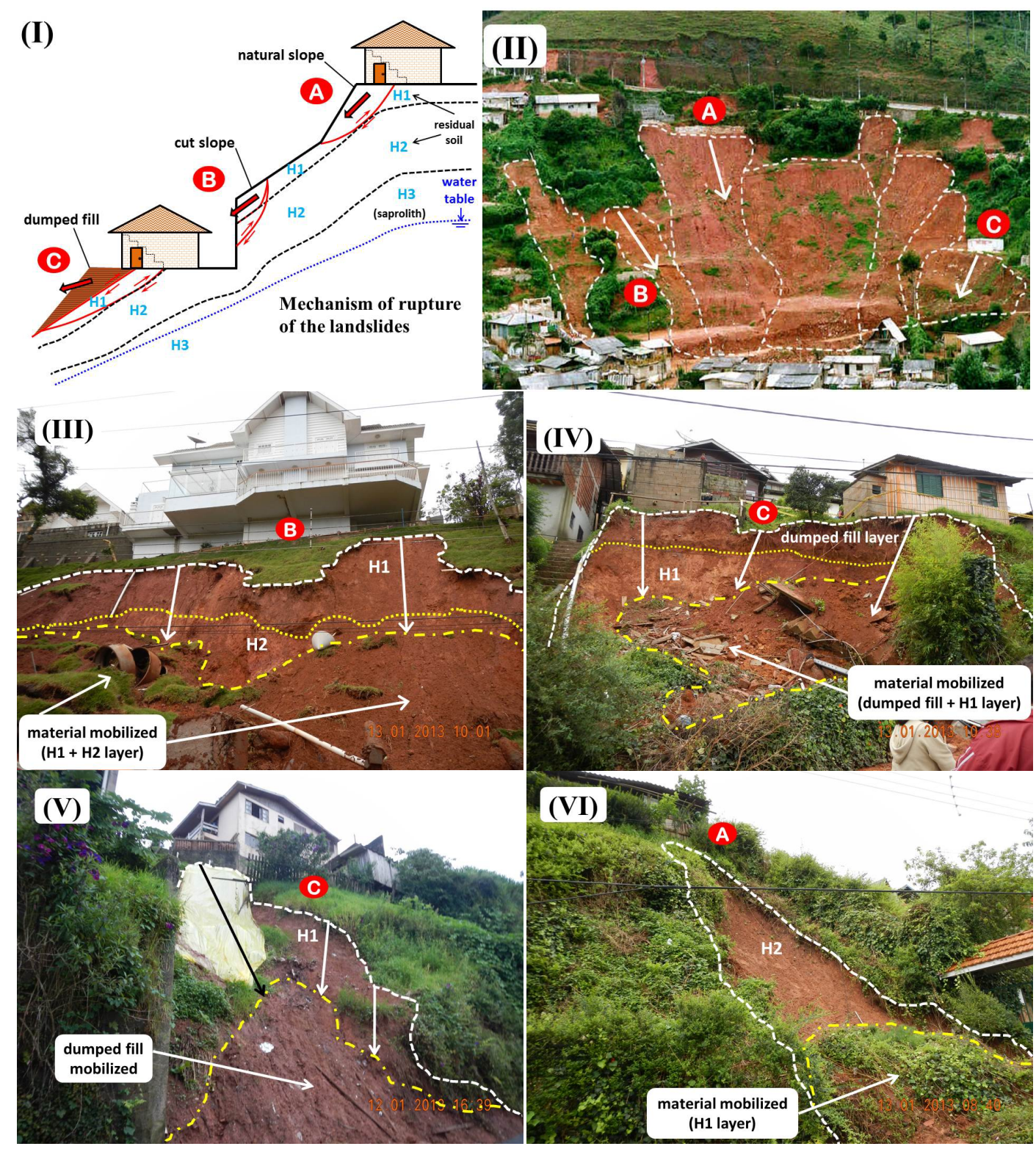

Figure 5. (I) Characteristics and main failure mechanisms of landslides in the study areas; (II) Landslides occurred in Campos do Jordão in the year 2000 [48]; (III), (IV), (V) and (VI) landslides of the types B, C (H1), C (dumped fill) and A, respectively, occurred in Campos do Jordão between 01/11/2013 and 01/13/2013 (Source: Geological Institute).

heavy rain from January 3 to 4, 2013, based on the accumulated precipitation data that were recorded by the automatic environmental station of Picinguaba (near the landslide) (Figure 10).

Overall, three landslides occurred in Ubatuba between 01/03/2013 and 01/04/2013 (Figure 10; yellow dots 1, 2 and 3). These landslides occurred on natural, un-developed slopes. However, some type of intervention occurred at the base of the slopes (work projects cut/dumped fills for construction of highway BR 101).

During these events in Ubatuba, the automatic environmental station (AES/INPE) near the three landslide points (yellow dots 1, 2 and 3) recorded the following information between 01/03/2013 and 01/04/2013: 125.0 accumulated rainfall in $24 \mathrm{~h}$, mean soil temperature of $28.5^{\circ} \mathrm{C}$ and a volumetric moisture content of $0.45 \mathrm{~m}^{3} / \mathrm{m}^{3}$ (Figure 10). Despite the considerable distance between the AES/INPE and the experimental field monitoring station of Ubatuba (Ef-3), very similar soil temperature $\left(28^{\circ} \mathrm{C}\right)$ and moisture $\left(0.46 \mathrm{~m}^{3} / \mathrm{m}^{3}\right)$ data were recorded between the landslides (Figure 14). In addition, the amounts of accumulated precipitation over $24 \mathrm{~h}$ were 


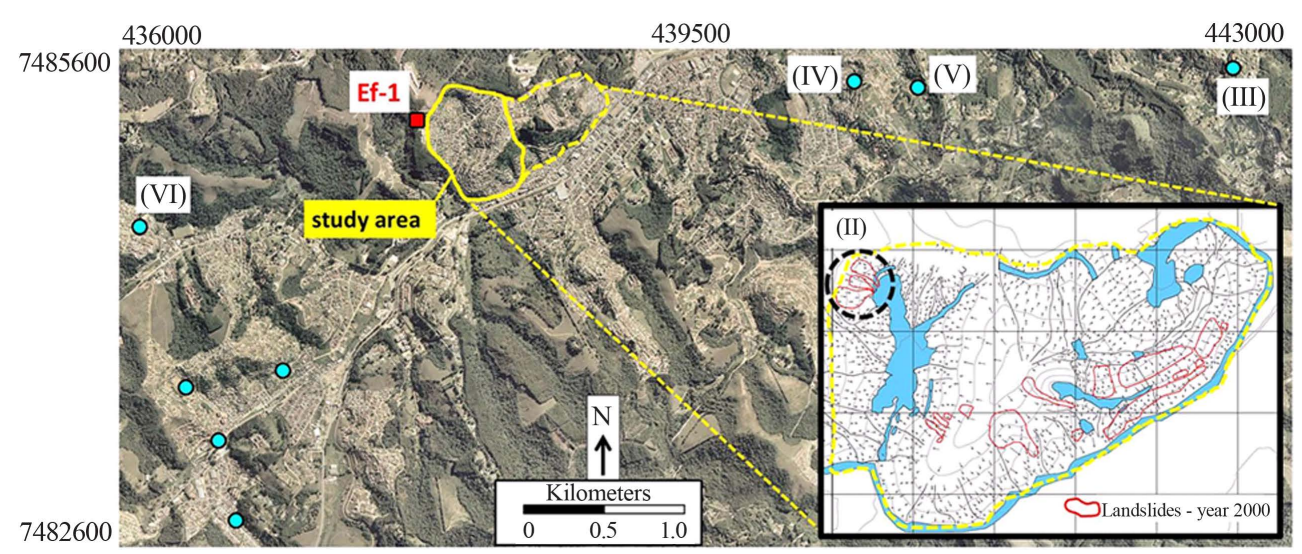

Figure 6. Landslides occurred in Campos do Jordão in the year 2000 (red polygons on map, [48]) and landslides occurred in Campos do Jordão between 01/11/2013 and 01/13/2013 (blue dots, source: Geological Institute), the numbers II, III, IV, V and VI refer to the landslides presented in Figure 5.
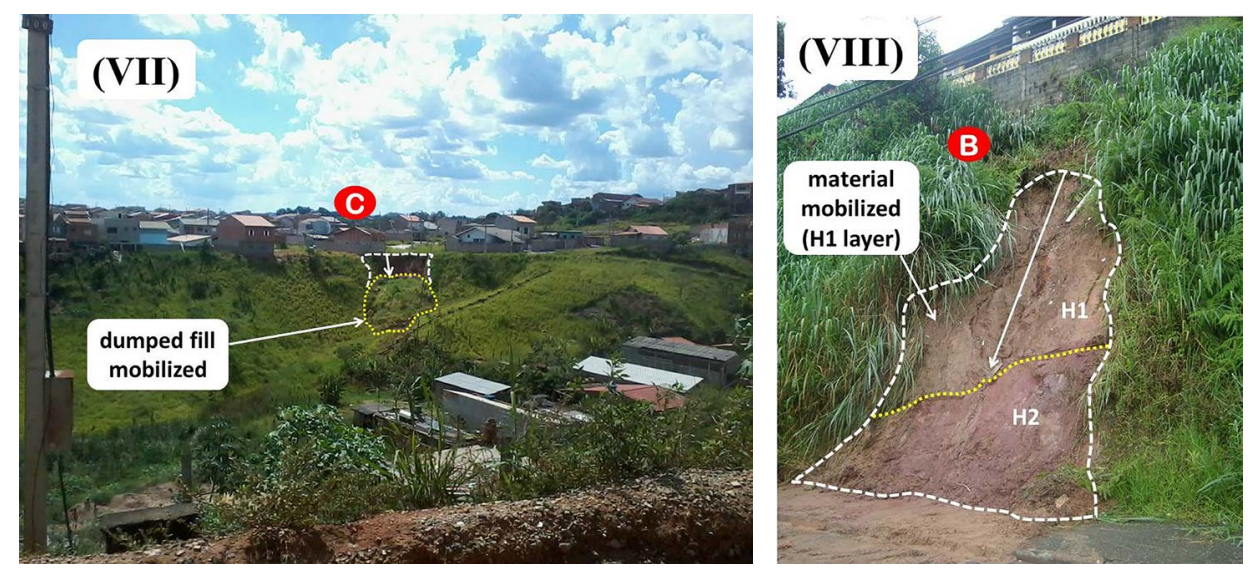

Figure 7. (VII) and (VIII) landslides of the type C (dumped fill) and B, respectively, occurred in São José dos Campos between 01/10/2013 and 01/11/2013 (Sources: VII, authors and VIII, Civil Defense of São José dos Campos).

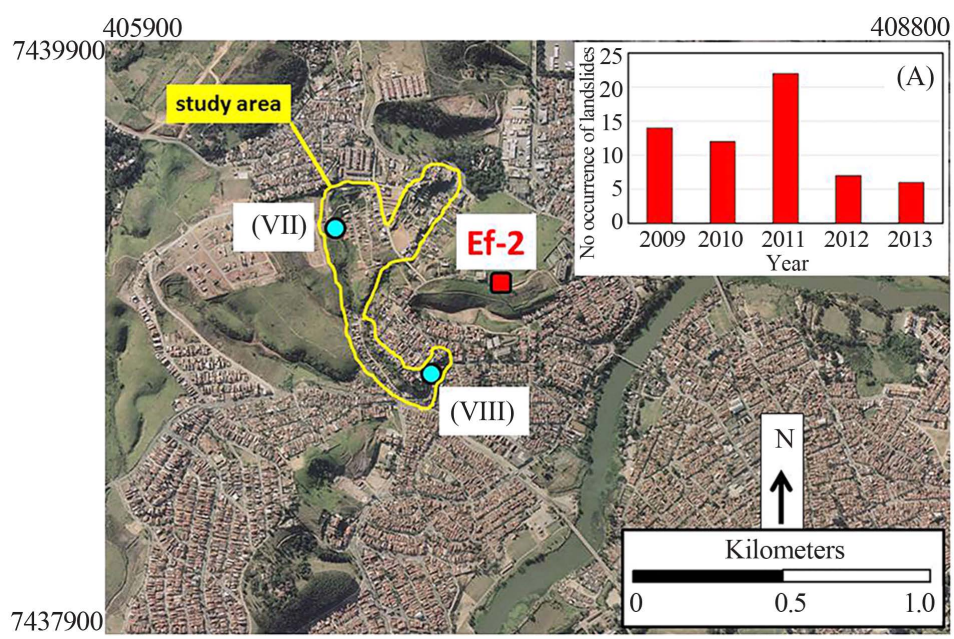

Figure 8. Localization of the landslides occurred in São José dos Campos between 01/10/2013 and 01/11/2013 (blue dots, sources: VII, authors, VIII, Civil Defense of São José dos Campos), the blue dots VII and VIII refer to the landslides presented in the Figure 7; (A) record of landslides occurred in São José dos Campos in the last five years (Source: Civil Defense of São José dos Campos). 

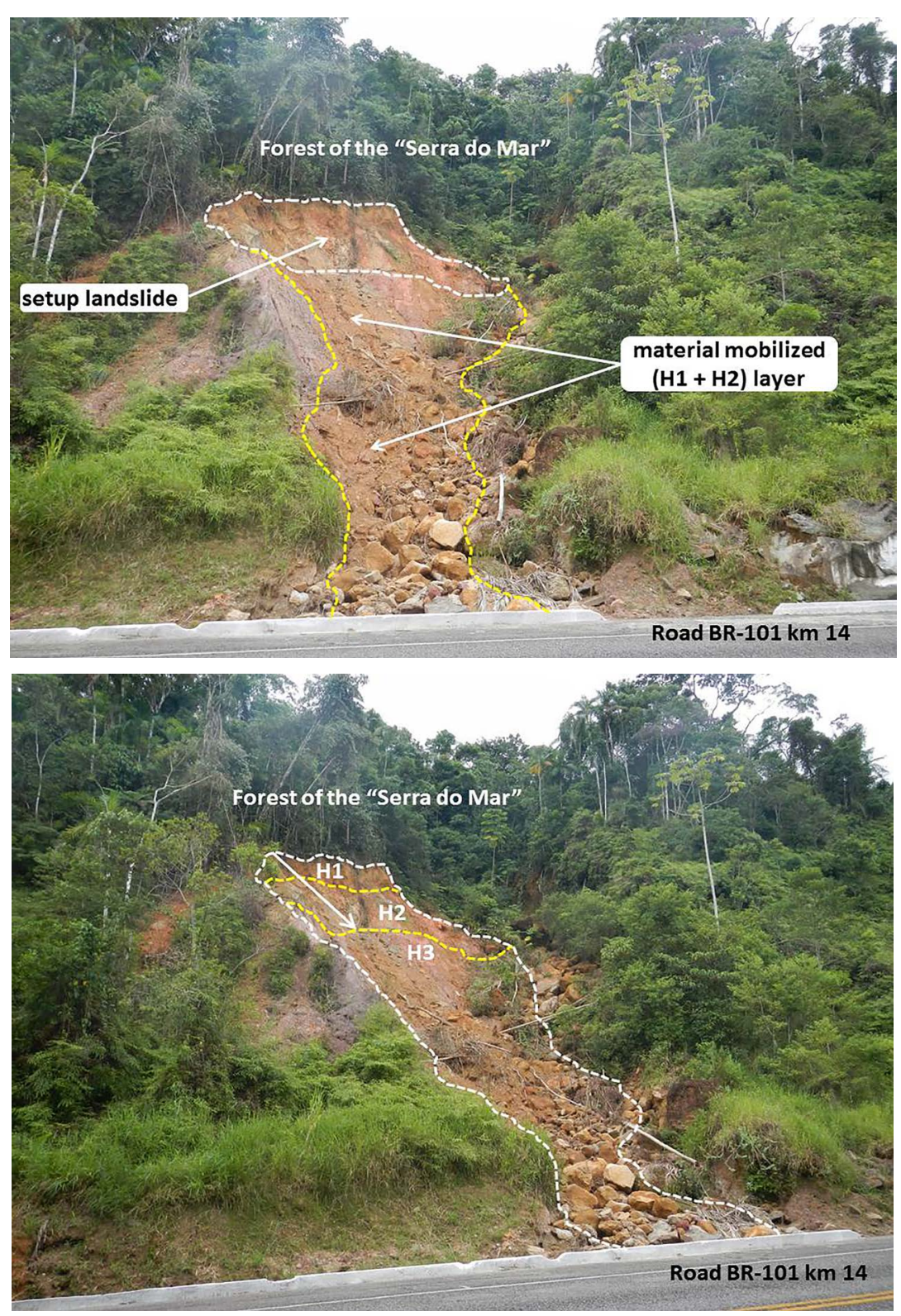

Figure 9. Reactivation of landslide on the slope of Serra do Mar (yellow dot 2 in Figure 10), occurred in Ubatuba between 01/03/2013 and 01/04/2013 in the km 14 of the highway BR-101 (Source: Geological Institute).

significantly different $(40.0 \mathrm{~mm})$.

In general, the anthropic activities interfered with the landslide rupture mechanisms in the studied urban areas, especially for slope cuts and dumped fill materials, regarding the amounts of hourly or daily rainfall needed to promote landslides. Thus, human interventions in densely populated risk areas significantly reduce the amount of rain that is required to generate landslides relative to other areas with low levels of human occupation and intervention.

\section{Experimental Site Implementation}

\subsection{In Situ Monitoring Sensor Installation}

Equipment and monitoring sensors were installed in soil profiles that represented the experimental soil profiles 


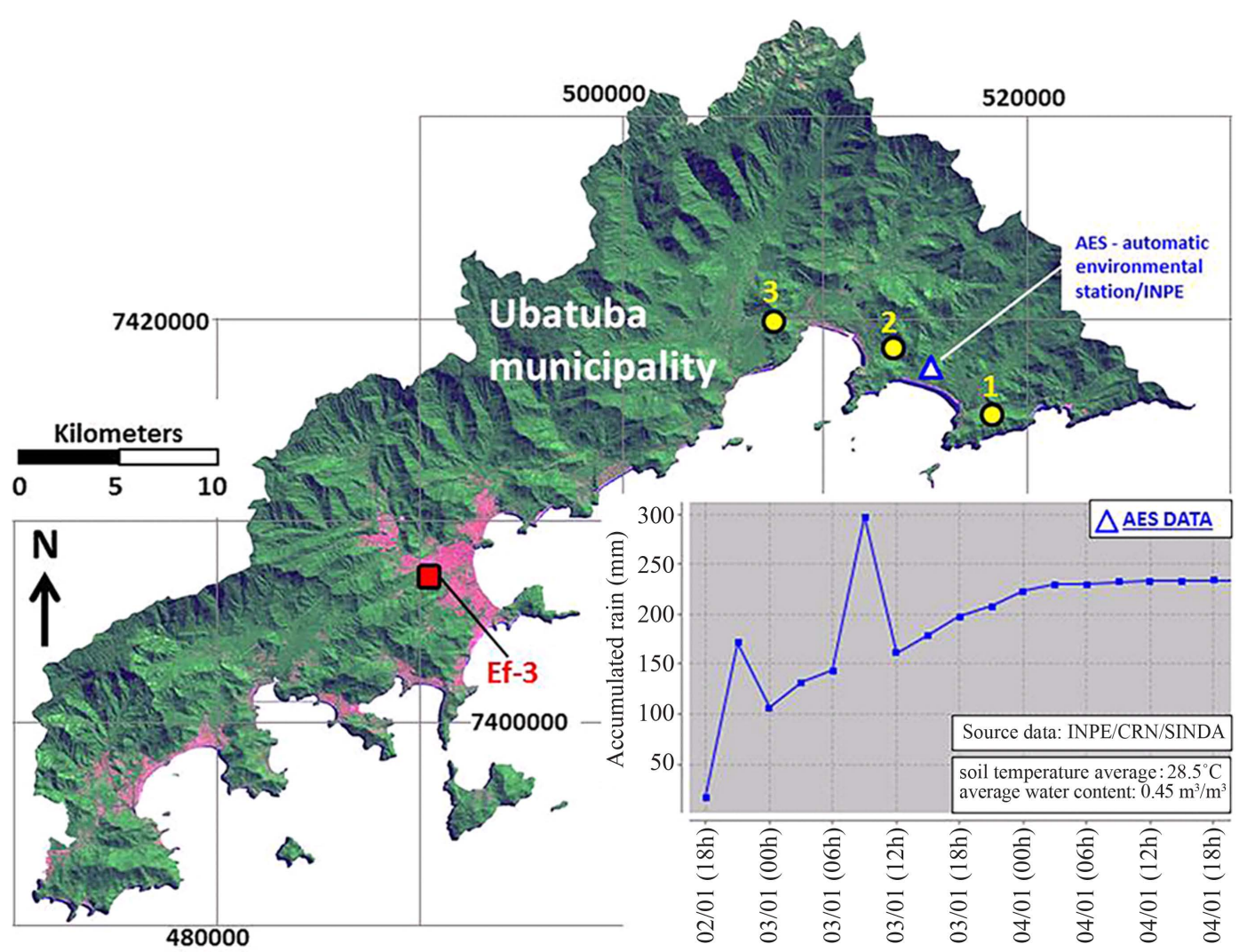

Figure 10. Localization of the landslides occurred in Ubatuba between 01/03/2013 and 01/04/2013 (yellow dots 1, 2, e 3, [54]), the yellow dot 2 refer to the landslide presented in Figure 9; the data of temperature and moisture of the soil represent the average values of the soil profile up 0.50 meter deep [55].

in the Campos do Jordão (Ef-1), São José dos Campos (Ef-2) and Ubatuba (Ef-3) fields as shown in Figure 4. To install sensors and other equipment that make up the "Monitoring System of the Experimental Plots", the installation recommendations of the manufacturer (Decagon Devices) were followed. Briefly, the following procedures were used. 1) Soil suction and temperature sensor (MPS-2 dielectric potential sensor). Initially, an auger was used to make a hole that was of the depth of the sensor installation depth. Next, the sensor was placed in the "installation system" and wrapped in a moist mass of the same soil that was removed from the bottom of the hole. Finally, the sensor was inserted into the hole to its base (steps A/B/C of Figure 11). 2) Soil moisture sensor (10HS soil moisture). Initially, an auger was used to make a hole that was the depth of the sensor installation depth. Next, the sensor was inserted directly into the hole to its base. In this case, the "installation system" that was developed specifically for this project (steps D/E Figure 11) was used. 3) Rain gauge and automatic data acquisition and transmission system (Em50G collect automatic system date). The rainfall gauge (rainfall) and the automatic data acquisition and transmission devices were installed directly in two rigid PVC tubes before directly connecting the rainfall sensor, soil moisture and suction cables to the data acquisition system. The data acquisition system consisted of two data loggers with five channels each (steps F/G/H of Figure 11).

\subsection{Analysis of the Monitored Data from the Experimental Plots}

The in situ monitoring of climatic and geotechnical data in the three experimental plots (Ef-1, Ef-2 and Ef-3) allowed for the joint analysis of emergency records and the Preventive Plan of Civil Defense (PPDC) during a period with multiple landslides (12/01/2012 to 04/30/2013). For this analysis, the data recorded by the field sensors (rainfall, soil moisture, soil suction and temperature) were analyzed with the landslide occurrences that were recorded during the PPDC operation. The in situ measurements of rainfall, soil moisture, soil suction and temperature were taken at 10-minute intervals and the data were automatically stored in data loggers every $4 \mathrm{~h}$ for a total of six (06) measurements per day. In Figures 12-14, the data recorded by all of the monitoring 


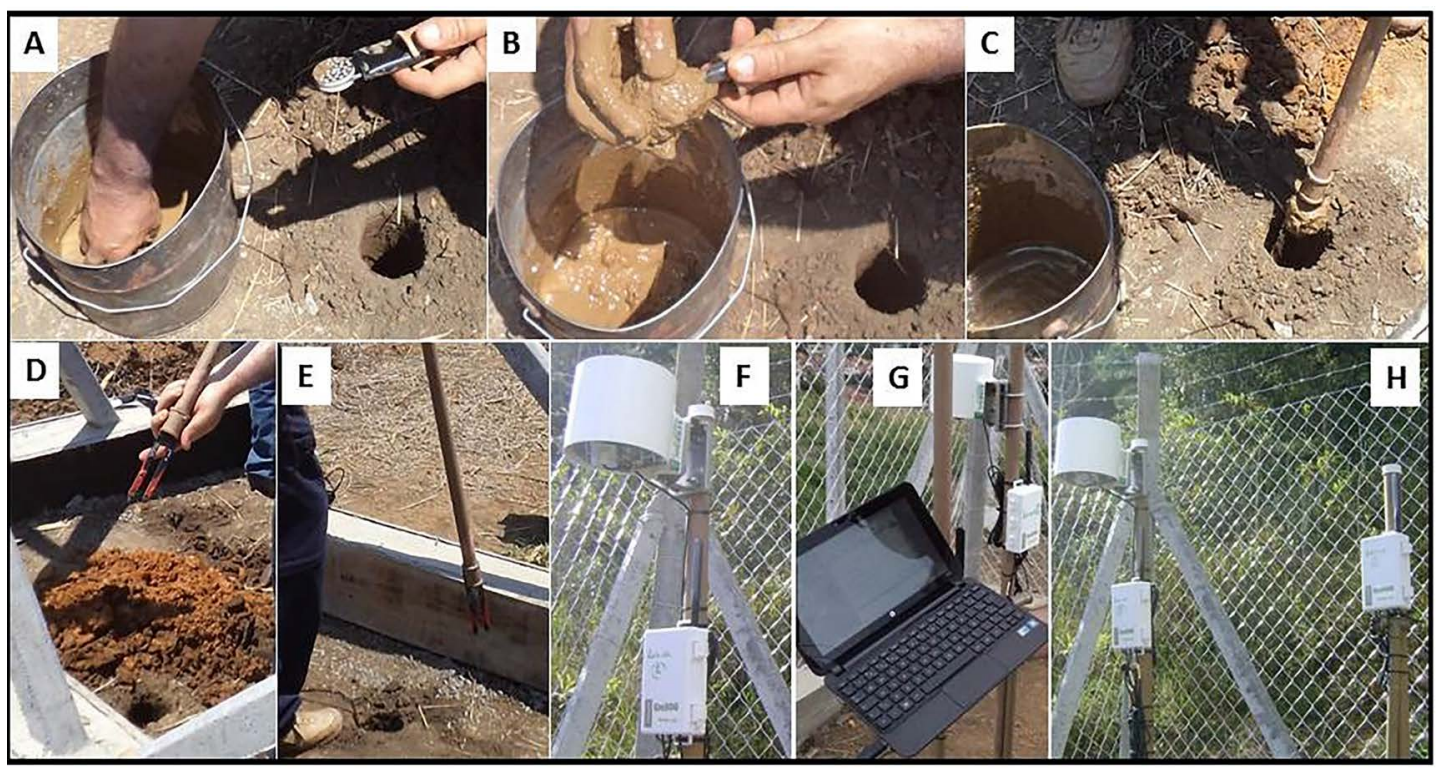

Figure 11. Installation of in situ monitoring sensors (A/B/C, soil suction and temperature sensors; D/E, soil moisture sensor), automatic data acquisition systems and rain gauges ( $\mathrm{F} / \mathrm{G} / \mathrm{H}$, rain sensor with data loggers with data transmission via the Global System for Mobile Communications, GSM/GPRS cellular technology).

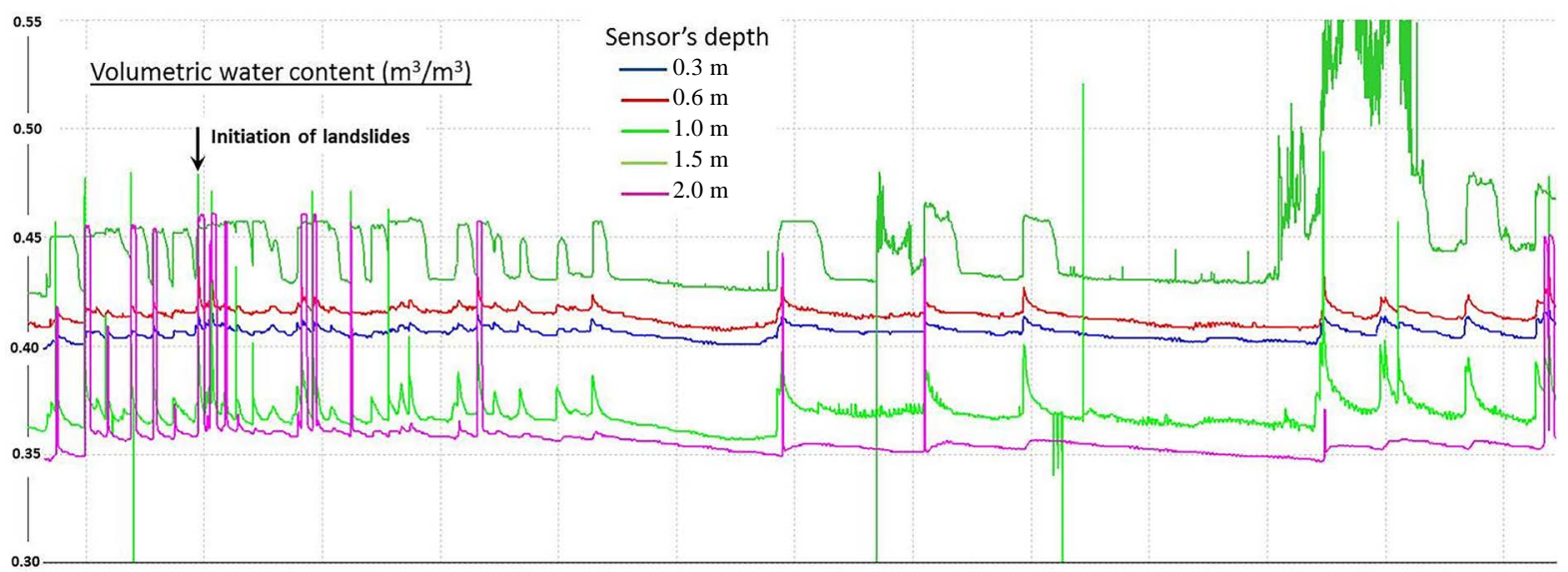

(a)

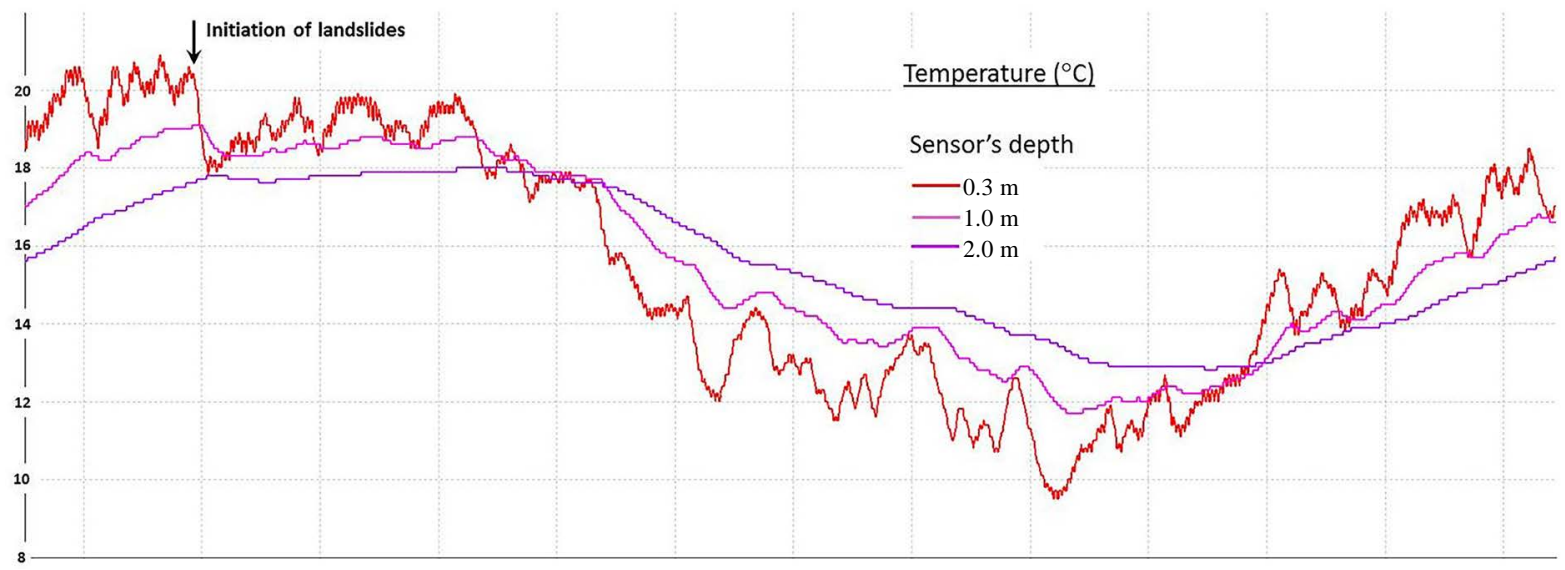




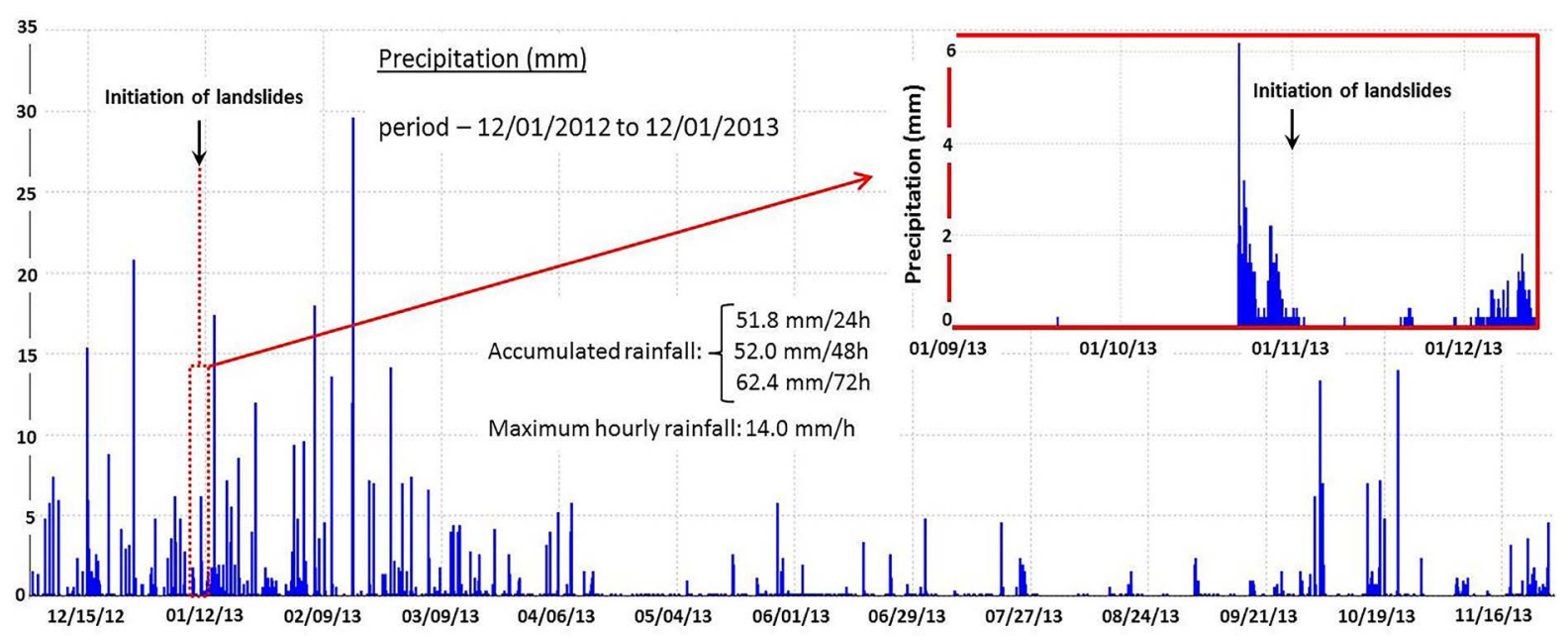

(c)

Figure 12. Monitoring data from the precipitation, soil temperature and soil moisture sensors in the experimental plot of Campos do Jordão (Ef-1) from 12/01/2012 to 12/01/2013, the main period of observed landslides (01/11/2013 to 01/12/2013, indicated by black arrows).

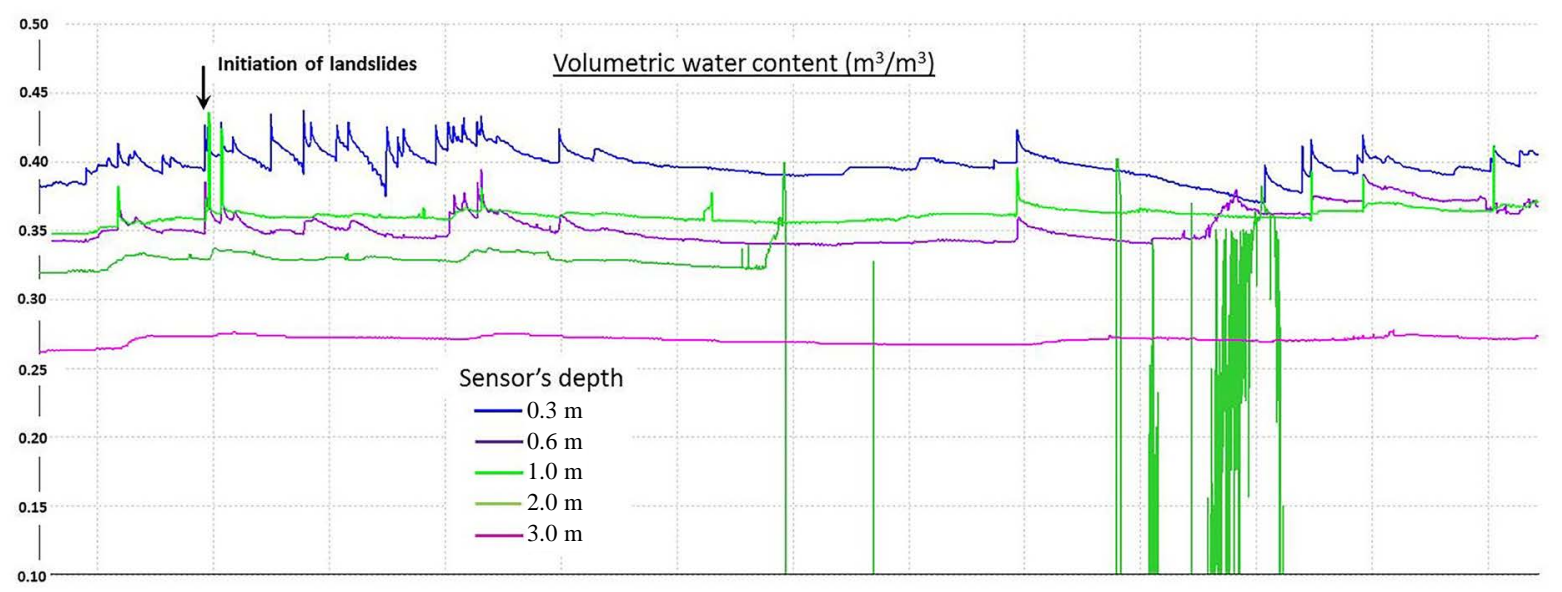

(a)

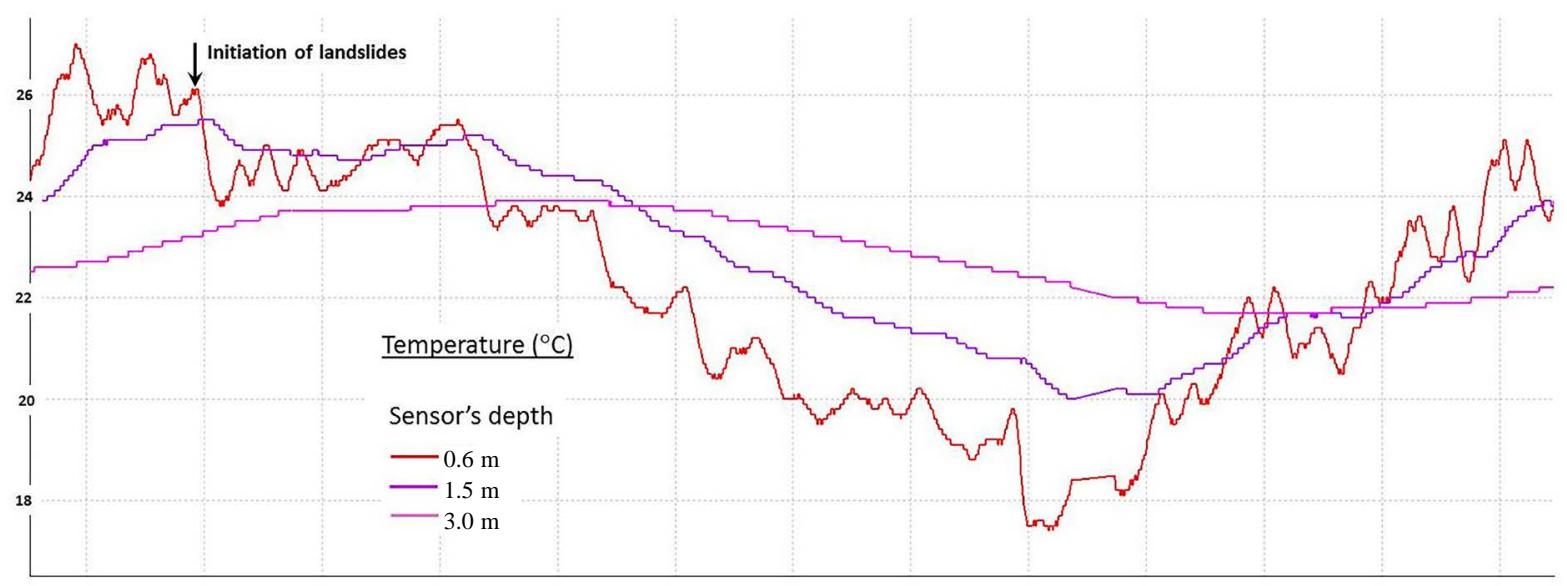

(b) 


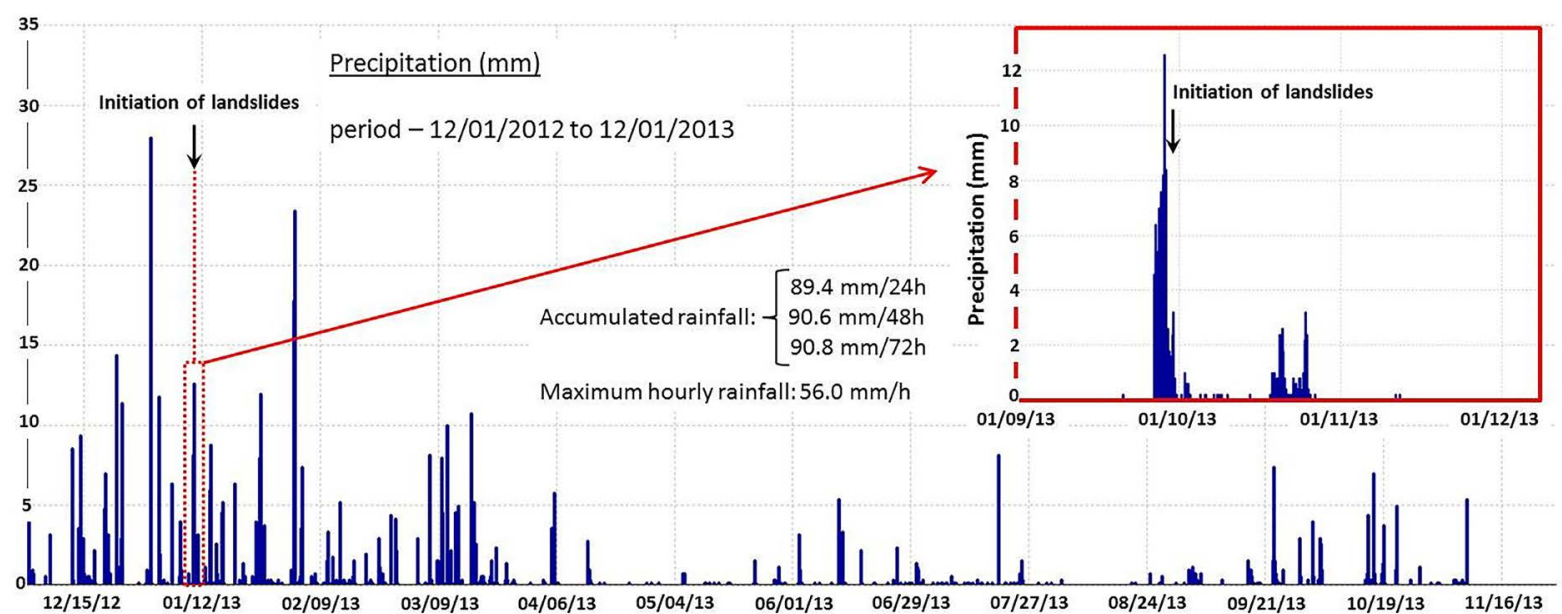

(c)

Figure 13. Monitoring data from the precipitation, soil temperature and soil moisture sensors in the experimental plot of São José dos Campos (Ef-2) from 12/01/2012 to 12/01/2013, the main period of observed landslides (01/10/2013 to 01/11/2013, indicated by black arrows).

systems in the three experimental fields are presented (Ef-1, Ef-2 and Ef-3) for the period between 12/01/2012 and 12/01/2013. Along with the climatic and geotechnical data that were recorded during the period, Figures 12-14 show the most probable regions of landslide outbreaks that were recorded during the study period (black arrows). These landslide regions included 1) the Campos do Jordão, 08 landslides (beginning on 01/11/2013); 2) the São José dos Campos, 02 landslides (beginning on 01/10/2013) and 3) the Ubatuba, 03 landslides (beginning on 01/04/2013).

The climatic and geotechnical data that were recorded by the monitoring systems of the experimental field of Campos do Jordão (Ef-1) are shown in Figure 12. Here, the initial day (01/11/2013) of the 08 landslides recorded in the county during operation of the PPDC are indicated. By considering the rainfall data for the entire study period (Figure 12), the greatest rainfall concentration occurred between 12/01/12 and 04/30/13 (totaling $1832 \mathrm{~mm}$ of precipitation). This rainfall accounted for approximately $80 \%$ of the total rainfall that was recorded throughout the entire monitoring period $(2334 \mathrm{~mm})$, with a maximum rainfall intensity of approximately 30.0 $\mathrm{mm} / 10$ minutes on 02/15/13. When considering the early landslides on $01 / 11 / 13$, the monitoring system of Campos do Jordão (Ef-1) recorded the following rainfall data (Figure 12, in detail): accumulated precipitation rates of $51.8 \mathrm{~mm} / 24 \mathrm{~h}, 52.0 \mathrm{~mm} / 48 \mathrm{~h}$ and $62.4 \mathrm{~mm} / 72 \mathrm{~h}$ and a maximum hourly rainfall rate of $14 \mathrm{~mm} / \mathrm{h}$. By only analyzing the rainfall data (Figure 12), the accumulated rainfall of $51.8 \mathrm{~mm} / 24 \mathrm{~h}$ was more significant. Thus, this rainfall accumulation was more effective for increasing the soil moisture content, which resulted in an outbreak of landslide events in Campos do Jordão. In addition, when analyzing soil moisture and temperature data (shown in Figure 12), the soil temperature values were among the highest that were recorded during the monitoring period on the day of landslide onset (black arrows) $\left(20.6^{\circ} \mathrm{C} / 0.3 \mathrm{~m}, 19.1^{\circ} \mathrm{C} / 1.0 \mathrm{~m}, 17.7^{\circ} \mathrm{C} / 2.0 \mathrm{~m}\right) . \mathrm{In}$ addition, the values of volumetric soil moisture were the highest among the values that were recorded throughout the study period $\left(0.41 \mathrm{~m}^{3} \cdot \mathrm{m}^{-3} / 0.3 \mathrm{~m} ; 0.44 \mathrm{~m}^{3} \cdot \mathrm{m}^{-3} / 0.6 \mathrm{~m} ; 0.48 \mathrm{~m}^{3} \cdot \mathrm{m}^{-3} / 1.0 \mathrm{~m} ; 0.46 \mathrm{~m}^{3} \cdot \mathrm{m}^{-3} / 1.5 \mathrm{~m}\right.$ and 0.46 $\mathrm{m}^{3} \cdot \mathrm{m}^{-3} / 2.0 \mathrm{~m}$ ). By carefully analyzing the behavior of the moisture profile during the landslide periods (Figure 12), the soil moisture distribution throughout the soil profile was considerably different relative to other rainfall events. This difference was especially true when considering the drainage of the soil profiles (i.e., moments before the start of the landslides, all sensors recorded an increase in soil moisture that considered the delay measurement between the sensors due to their positions in the soil profile) before they reached their maximum values. These soils remained in this condition for approximately 2 h/0.3 m, 5 h/0.6 m, 2 h/1.0 m, 12 d/1.5 m and 30 $\mathrm{h} / 2.0 \mathrm{~m}$.

This spatial-temporal behavior distribution of moisture in the soil profile enhanced the soil temperature values and played an essential rule in the occurrences of landslides in the study area. This finding was demonstrated by the monitoring data of the other experimental fields (Figure 13 and Figure 14), where 02 landslides were recorded in the municipality of São José dos Campos (starting day, 01/10/2013) and 03 landslides were recorded 


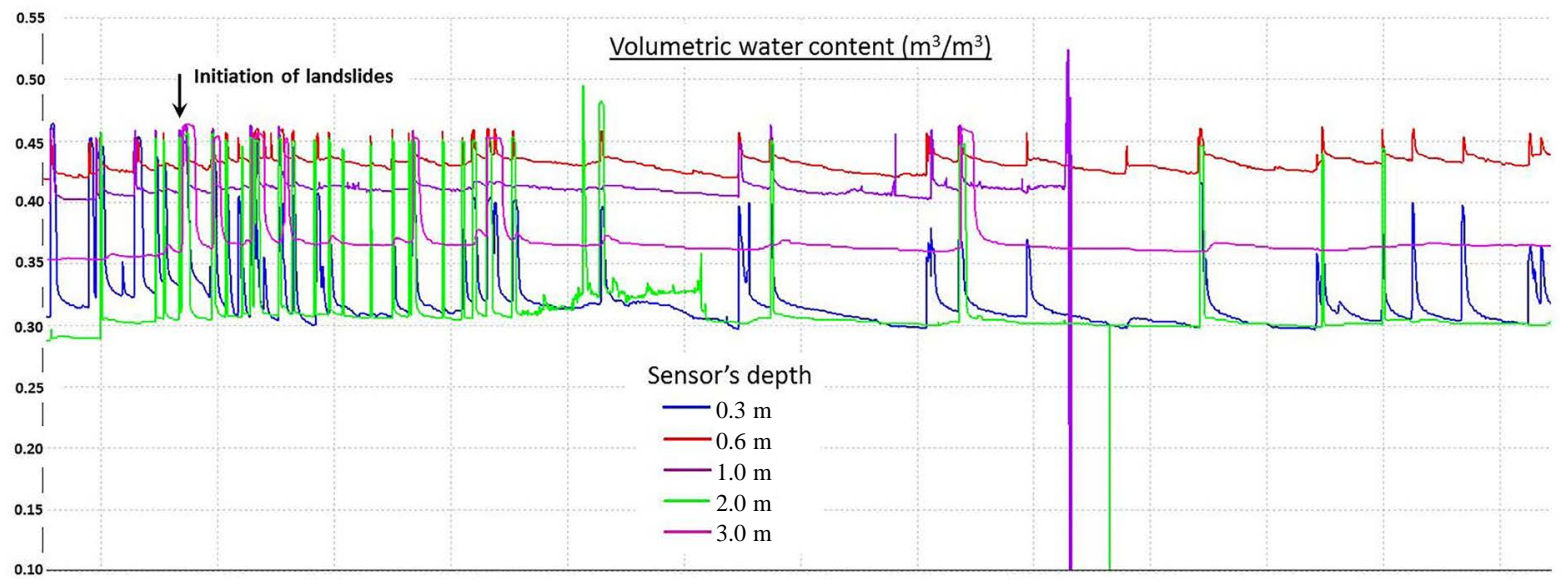

(a)

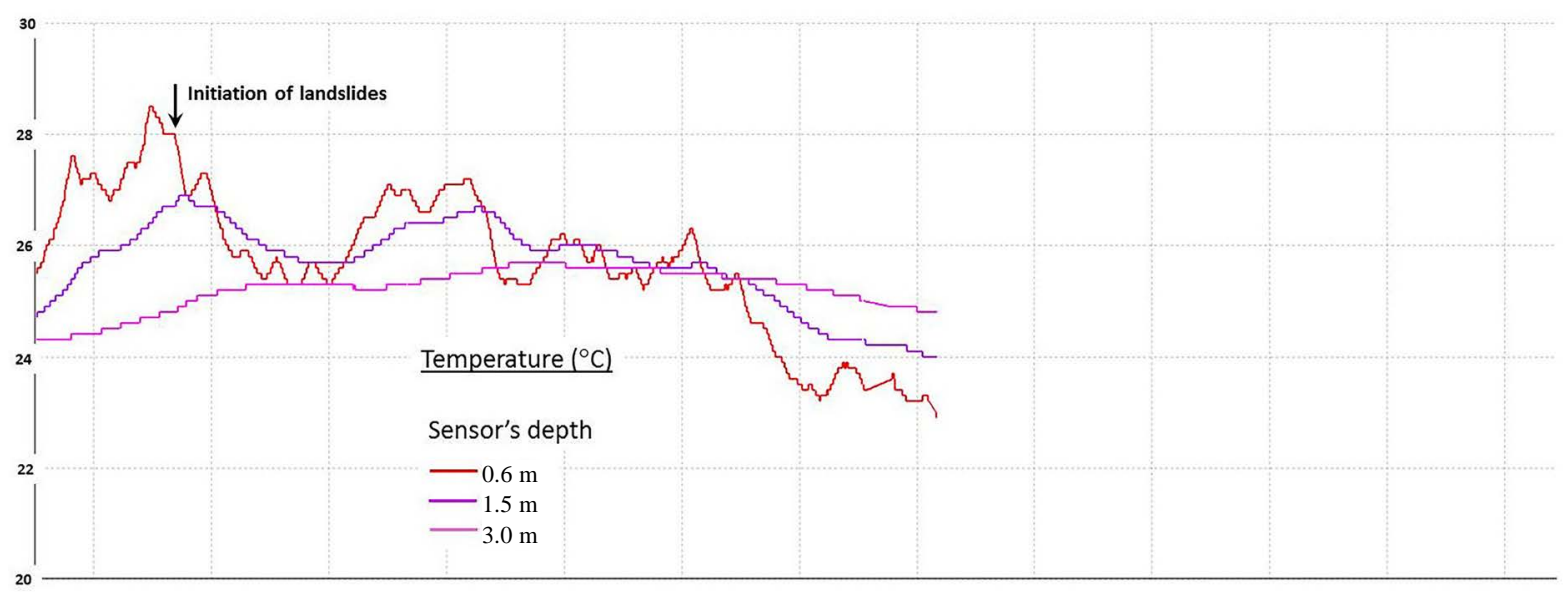

(b)

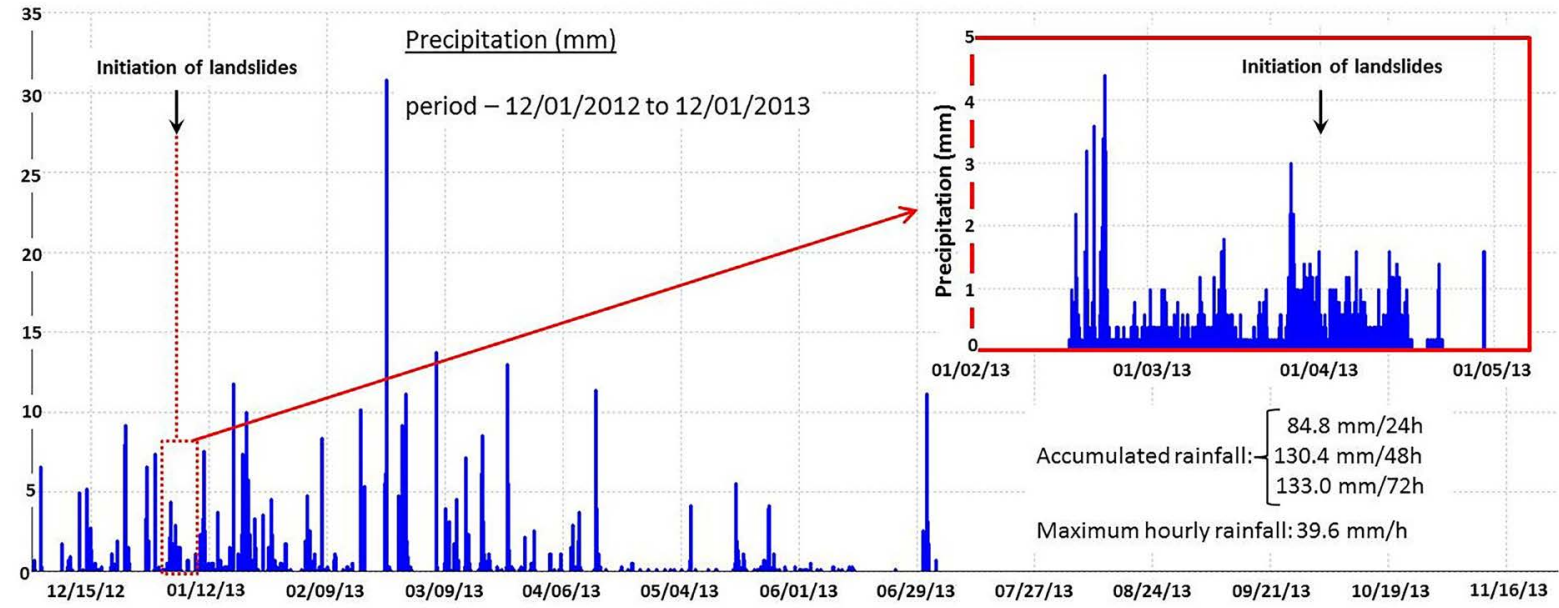

(c)

Figure 14. Monitoring data from the precipitation, soil temperature and soil moisture sensors in the experimental plot of Ubatuba (Ef-3) from 12/01/2012 to 12/01/2013, the main period of observed landslides (01/03/2013 to 01/04/2013, indicated by black arrows).

in Ubatuba (starting day, 01/04/2013). 
When analyzing data from the experimental fields of São José dos Campos (Ef-2) and Ubatuba (Ef-3) (shown in Figure 13 and Figure 14, respectively), similar behavior was observed in the spatial-temporal distribution of the soil moisture profile and high soil temperature values on days of landslide onset (black arrows). At the beginning of the landslides in the municipality of São José dos Campos (Figure 13), the soil temperatures were the highest on record during the monitoring period $\left(26.1^{\circ} \mathrm{C} / 0.6 \mathrm{~m} ; 25.5^{\circ} \mathrm{C} / 1.5 \mathrm{~m} ; 23.4^{\circ} \mathrm{C} / 3.0 \mathrm{~m}\right)$. The volumetric soil moisture contents were also the highest recorded during this period $\left(0.43 \mathrm{~m}^{3} \cdot \mathrm{m}^{-3} / 0.3 \mathrm{~m} ; 0.39 \mathrm{~m}^{3} \cdot \mathrm{m}^{-3} / 0.6 \mathrm{~m} ; 0.44\right.$ $\mathrm{m}^{3} \cdot \mathrm{m}^{-3} / 1.0 \mathrm{~m} ; 0.34 \mathrm{~m}^{3} \cdot \mathrm{m}^{-3} / 2.0 \mathrm{~m}$ and $0.28 \mathrm{~m}^{3} \cdot \mathrm{m}^{-3} / 3.0 \mathrm{~m}$ ), indicating changes in the moisture of the most superficial layers of soil $(0.3 \mathrm{~m}, 0.6 \mathrm{~m}$ and $1.0 \mathrm{~m})$. Furthermore, at the beginning of the landslides in Ubatuba (Figure 14), the soil temperatures were the highest on record during the monitoring period $\left(28.0^{\circ} \mathrm{C} / 0.6 \mathrm{~m} ; 27.0^{\circ} \mathrm{C} / 1.5 \mathrm{~m}\right.$; $25.0^{\circ} \mathrm{C} / 3.0 \mathrm{~m}$ ). In addition, the volumetric soil moisture contents were the highest on record during the monitoring period $\left(0.45 \mathrm{~m}^{3} \cdot \mathrm{m}^{-3} / 0.3 \mathrm{~m} ; 0.46 \mathrm{~m}^{3} \cdot \mathrm{m}^{-3} / 0.6 \mathrm{~m} ; 0.46 \mathrm{~m}^{3} \cdot \mathrm{m}^{-3} / 1.0 \mathrm{~m} ; 0.45 \mathrm{~m}^{3} \cdot \mathrm{m}^{-3} / 2.0 \mathrm{~m} ; 0.46 \mathrm{~m}^{3} \cdot \mathrm{m}^{-3} / 3.0 \mathrm{~m}\right)$.

When analyzing rainfall data from the monitoring period of the experimental fields of São José dos Campos and Ubatuba (Figure 13 and Figure 14, respectively), greater rainfall concentrations occurred between 12/01/12 and 04/30/13, which totaled 1207 and $1806 \mathrm{~mm}$ of rainfall, respectively. That is, $76 \%$ of the total rainfall recorded in the São José dos Campos experimental plot $(1584 \mathrm{~mm})$ and $89 \%$ of the total rainfall recorded in the Ubatuba experimental plot (1584 mm through 07/03/2013, after this date, no additional rainfall and soil temperature data were collected due to technical problems with the data logger). The maximum rain intensities that were recorded in the experimental fields of São José dos Campos and Ubatuba were approximately $28.0 \mathrm{~mm} / 10$ minutes on 12/30/12 (Figure 13) and $30.8 \mathrm{~mm} / 10$ minutes on 02/22/13 (Figure 14), respectively.

At the beginning of the landslides on 1/10/13, the São José dos Campos monitoring system (Ef-2) recorded the following rainfall data (Figure 13, in detail): accumulated precipitation of $89.4 \mathrm{~mm} / 24 \mathrm{~h}, 90.6 \mathrm{~mm} / 48 \mathrm{~h}$ and $90.8 \mathrm{~mm} / 72 \mathrm{~h}$ and a maximum hourly rainfall of $56 \mathrm{~mm} / \mathrm{h}$. Based on the rainfall data (Figure 13), a rain accumulation of $89.4 \mathrm{~mm} / 24 \mathrm{~h}$ with an intensity of $56 \mathrm{~mm} / \mathrm{h}$ was potentially correlated to the outbreak of landslides in São José dos Campos. Regarding the monitoring system of Ubatuba (Ef-3), the landslide that occurred on 01/04/13 on highway BR 101 corresponded with the following rainfall data (Figure 14, in detail): accumulated precipitation of $84.8 \mathrm{~mm} / 24 \mathrm{~h}, 130.4 \mathrm{~mm} / 48 \mathrm{~h}$ and $133.0 \mathrm{~mm} / 72 \mathrm{~h}$ and a maximum hourly rainfall of $39.6 \mathrm{~mm} / \mathrm{h}$. The monitoring data from the experimental field of Ubatuba (Figure 14) should be analyzed with caveats, mainly due to the considerable distance between the experimental and field locations of the landslides. However, based on the data that were recorded by the automatic environmental station installed next to the landslide location (Figure 10), very similar soil temperature and soil moisture values were recorded in the experimental plot of Ubatuba (Ef-3). Specifically, the average soil temperature and volumetric moisture contents were 28.5 to $28.0^{\circ} \mathrm{C}$ and 0.45 to $0.46 \mathrm{~m}^{3} \cdot \mathrm{m}^{-3}$, respectively. For the values of accumulated precipitation in $24 \mathrm{~h}$, a significant difference of approximately $40.0 \mathrm{~mm}$ (125.0 mm and $84.8 \mathrm{~mm}$, respectively) occurred. The difference between the rain accumulation/ $24 \mathrm{~h}$ values that were recorded during the landslides in the monitored municipalities may indicate the importance of human activities in creating landslides.

Measured anomalies were temporarily or permanently displayed by some moisture sensors (10HS) in the experimental plots of Campos do Jordão (Figure 12, sensors installed at 1.0 and $1.5 \mathrm{~m}$ ), São José dos Campos (Figure 13, sensor installed at $2.0 \mathrm{~m}$ ) and Ubatuba (Figure 14, sensors installed at 1.0 and $2.0 \mathrm{~m}$ ). These anomalies were due to the lack of temporary or permanent contact between the moisture sensors and the adjacent soil (predominantly clayey soil existing at these depths). The performance of volumetric moisture sensors (using the FDR technology - Frequency Domain Reflectometry) depends on the integrity of the moisture sensor's contact with the surrounding soil. Thus, the spaces (voids) that formed after the sensor installation in clayey layers (due to the shrinkage of the clay soil during the dry season) impaired the performance of these sensors for measuring the volumetric soil moisture content.

\section{Final Considerations}

The rupture mechanisms of landslides (Figure 5), geological and geotechnical characteristics, geomorphological conditions, existence of a deep water table, presence of unsaturated soil profile and the in situ monitoring data from the experimental plots (Ef-1, and Ef-2 and Ef-3) were considered. The environmental conditions that triggered landslides in the study areas were concurrent and included a significant increase in volumetric soil water content throughout the soil profile (up to $3.0 \mathrm{~m}$ deep), heavy rainfall ( $>35 \mathrm{~mm} / \mathrm{h}$ ) and/or cumulative rainfall of more than $50 \mathrm{~mm} / 24 \mathrm{~h}$ and the high soil temperature values before heavy rains. 
Based on the data analysis of the recorded soil moisture values in the experimental fields (Ef-1, Ef-2 and Ef-3), the critical values of soil moisture along the soil profiles where landslides were triggered were identified. For the studied soil profiles, the critical values of volumetric moisture were between 0.40 and $0.45 \mathrm{~m}^{3} / \mathrm{m}^{3}$, depending on the depth of the installed sensor. Furthermore, for landslides to occur, the volumetric moisture content must significant increase in the surface layers that are prone to soil rupture (usually between 1.0 to $2.0 \mathrm{~m}$ ). In addition, the reading delay of the moisture sensors must be considered.

The accumulated rainfall data that were recorded in the municipalities of Campos do Jordão (Figure 12), São José dos Campos (Figure 13) and Ubatuba (Figure 10 and Figure 14) were analyzed. An inverse relationship was found between urban densification in risk areas (Figure 3) or the level of human intervention on natural slopes (for example, highway construction, Figure 9) and an increase in the amount of rainfall required to trigger landslides in the study area. For example, higher levels of human intervention on natural slopes (slope cuts/ landfills, release of wastewater, overload, etc.) reduce the amount of accumulated precipitation required for a landslide outbreak. The real-time monitoring of rainfall intensity $(\mathrm{mm} / \mathrm{h})$ and precipitation accumulation $(\mathrm{mm} / 24$ h) is essential for predicting landslides in urban or other risk areas, particularly when they are densely occupied.

Based on the temperature data of the soil profile (Figures 12-14), a significant relationship existed between the high soil temperature values (especially the superficial layers; H1/H2, Figure 4) and the landslide outbreaks that were recorded in the studied cities. This relationship may occur because the hydraulic behavior variations of the soil are directly proportional to the soil temperature variations (i.e., the permeability increases with increasing soil temperature [56]).

Regarding the soil suction data in the experimental plots (Ef-1, Ef-2 and Ef-3), no significant variations occurred during the monitoring period, mainly due to the unsatisfactory precision of the sensors (MPS-2 dielectric potential) for suction readings in the range of -10 to $-100 \mathrm{kPa}$ (error $\pm 25 \%$ ). However, the real-time monitoring of soil suction with sensors that are more accurate will be fundamental for understanding the mechanisms that trigger landslides.

The real-time and simultaneous monitoring of precipitation, soil moisture and temperature are essential for understanding the outbreak of landslides in risk areas, especially for allowing in situ and real-time assessment of spatial and temporal rainfall, soil moisture and temperature distributions. In addition, these data promise to establish critical thresholds of climatic and geotechnical variables for use in landslide warning systems in densely populated areas.

\section{Acknowledgements}

The authors thank to Civil Defense of São José dos Campos by grant of the photos and of the landslides records data and too to Foundation for Research Support of the State of Sao Paulo by financial aid award (process number 2011/22577-2).

\section{References}

[1] Zuquette, L.V. and Pejon, O.J. (2004) Geological and Geotechnical Hazardous Events in Brazil. In: Brazilian Symposium on Natural Disaster, Florianópolis-SC, GEDN/UFSC, 312-336.

[2] Tatizana, C., Ogura, A.T., Cerri, L.E.S. and Rocha, M.C.M. (1987) Analysis of the Correlation between Rainfall and Landslides in the Serra do Mar, Municipality of Cubatão. Proceedings of the Brazilian Congress of Engineering Geology, 2, 225-236. (In Portuguese)

[3] Tatizana, C., Ogura, A.T., Cerri, L.E.S. and Rocha, M.C.M. (1987) Numerical Modeling of the Analysis of Correlation between Rainfall and Landslides Applied to the Slopes of the Serra do Mar in Municipality of Cubatão. Proceedings of the Brazilian Congress of Engineering Geology, 2, 237-248. (In Portuguese)

[4] Lumb, P. (1975) Slope Failures in Hong Kong. Quarterly Journal of Engineering Geology and Hydrogeology, 8, 31-65. http://dx.doi.org/10.1144/GSL.QJEG.1975.008.01.02

[5] Boonsinsuk, P., Yong, R.N. and Siu, S.K.H. (1982) Analysis of Hong Kong Residual Soil Slopes, Engineering and Constructions in Tropical and Residual Soil. ASCE Geotechnical Engineering Division, Honolulu, 463-482.

[6] Zaruba, Q. and Mencl, V. (1982) Landslides and Their Control: Development in Geotechnical Engineering. Elsevier, Amsterdam, 324 p.

[7] Brand, E.W., Premchitt, J. and Phillipson, H.B. (1984) Relationship between Rainfall and Landslides in Hong Kong. Proceedings of the 4th International Symposium on Landslides, Toronto, 16-21 September 1984, 377-384. 
[8] Anderson, M.G. and Pope, R.G. (1984) The Incorporation of Soil Water Models into Geotechnical Studies of Landslides Behavior. Proceedings of the 4th International Symposium on Landslides, Toronto, 16-21 September 1984, 349353.

[9] Canuti, P., Focardi, P. and Garzonio, C.A. (1985) Correlation between Rainfall and Landslides. Bulletin of the International Association of Engineering Geology, 32, 49-54. http://dx.doi.org/10.1007/BF02594765

[10] Keefer, D.K., Wilson, R.C., Mark, R.K., Brabb, E.E., Brown, W.M., Ellen, S.D., Harp, E.L., Wieczorek, G.F., Alger, C.S. and Zatkin, R.S. (1987) Real-Time Landslide Warning during Heavy Rainfall. Science, 238, 921-925. http://dx.doi.org/10.1126/science.238.4829.921

[11] Eyles, N. and Howard, K.W.F. (1988) A Hydrochemical Study of Urban Landslides Caused by Heavy Rain: Scarborough Bluffs, Ontario, Canada. Canadian Geotechnical Journal, 25, 455-466. http://dx.doi.org/10.1139/t88-051

[12] Matsuo, M. and Suzuki, H. (1988) Case Study of Slope Stability during Rainfall. Journal of Natural Disaster Science, 10, 15.

[13] Wieczorek, G.F. (1996) Landslide Triggering Mechanisms. In: Turner, A.K. and Schuster, R.L., Eds., Landslides: Investigation and Mitigation, Transportation Research Board, National Research Council, Special Report, Washington DC, 76-90.

[14] Anagnostopoulos, C. and Georgiadis, M. (1997) Analysis of Rainfall Data and Correlation to Landslides: The Case of Sykia-Pieria, Greece. In: Marinos, P.G., Koukis, G.C., Tsiambaos, G.C. and Stoumaras, G.C., Eds., Engineering Geology and the Environment, Balkema, Rotterdam, 483-487.

[15] Au, S.W.C. (1998) Rain-Induced Slope Instability in Hong Kong. Engineering Geology, 51, 1-36.

[16] Glade, T., Crozier, M.J. and Smith, P. (2000) Applying Probability Determination to Refine Landslide-Triggering Rainfall Thresholds Using an Empirical “Antecedent Daily Rainfall Model”. Pure and Applied Geophysics, 157, 10591079. http://dx.doi.org/10.1007/s000240050017

[17] Bacchini, M. and Zannoni, A. (2003) Relations between Rainfall and Triggering of Debris-Flow: A Case Study of Cancia (Dolomites, Northeastern Italy). Natural Hazards and Earth System Sciences, 3, 71-79. http://dx.doi.org/10.5194/nhess-3-71-2003

[18] Aleotti, P. (2004) A Warning System for Rainfall-Induced Shallow Failures. Engineering Geology, 73, 247-265. http://dx.doi.org/10.1016/j.enggeo.2004.01.007

[19] Quinta Ferreira, M., Lemos, L.J.L. and Pereira, L.F.M. (2005) Influence of Rainfall on the Occurrence of Landslides in Coimbra, in the Last 139 Years. Portuguese Geotechnical Journal, 104, 17-30. (In Portuguese)

[20] Chen, C.-Y., Chen, T.-C., Yu, F.-C., Yu, W.-H. and Tseng, C.-C. (2005) Rainfall Duration and Debris-Flow Initiated Studies for Real-Time Monitoring. Environmental Geology, 47, 715-724. http://dx.doi.org/10.1007/s00254-004-1203-0

[21] Guidicini, G. and Iwasa, O.Y. (1976) Test of Correlation between Rainfall and Landslides in a Humid Tropical Environment. Technological Research Institute/IPT, Sao Paulo, 48 p. (Internal Publication)

[22] Wolle, C.M. and Carvalho, C.S. (1989) Landslides on Slopes of Serra do Mar (Brazil). Soils and Rocks, ABMS/SPG: São Paulo, 12 (único): 27-36. (In Portuguese)

[23] Wolle, C.M. and Hachich, W. (1989) Rain-Induced Land-Slides in Southern Brazil. Proceedings of the 12th International Conference on Soil Mechanics and Foundation Engineering, Rio de Janeiro.

[24] Elbachá, A.T., Campos, L.E.P. and Bahia, R.F.C. (1992) Attempted of Correlation between Rainfall and Landslides in the City of Salvador. Proceedings of the Brazilian Conference on Stability of Slopes, 2, 647-673. (In Portuguese)

[25] Almeida, M.C.J., Nakazawa, A. and Tatizana, C. (1993) Analysis of Correlation between Rainfall and Landslides in the City of Petrópolis, RJ. Proceedings of the Brazilian Congress of Engineering Geology, 2, 129-133. (In Portuguese)

[26] Anjos, C.A.M., Cerri, L.E.S. and Gandolfi, N. (1997) Risk Situations and Measures to Prevent Accidents on Occupied Slopes in Maceio (AL), Brazil. Proceedings of the 2nd Pan-American Symposium of Landslides and Brazilian Conference on Slope Stability, Rio de Janeiro, 10-14 November 1997, 773-782. (In Portuguese)

[27] Gusmão Filho, J.A. (1997) Urban Slopes: Environmental, Social and Political Aspects. Proceedings of the 2nd PanAmerican Symposium of Landslides and Brazilian Conference on Slope Stability, Rio de Janeiro, 10-14 November 1997, 315-331. (In Portuguese)

[28] Feijó, R.L., Paes, N.M. and d'Orsi, R.N. (2001) Rainfall and Mass Movements in the City of Rio de Janeiro. Proceedings of the 3rd Brazilian Conference on Stability of Slopes, 1, 223-230. (In Portuguese)

[29] Pinheiro, A., Tachini, M. and Riekmann, C.G. (2005) Study of the Correlation between Rainfall and Landslides in Risk Areas of Blumenau-SC. In: Vieira, R. and Pinheiro, A., Eds., A Look at the Risk Areas to Landslides in the City of Blumenau: Seeking Prevention, FURB-IPA, Blumenau, 27-41. (In Portuguese)

[30] Macedo, E.S., Ogura, A.T. and Santoro, J. (2006) What Is a Contingency Plan or Preventive Plan of Civil Defense. In: Carvalho, C.S. and Galvão, T., Eds., Risk Prevention of Landslide in Slopes: Guide to Drafting of Municipal Policies, 
Ministério das Cidades, Brasília, 78-91. (In Portuguese)

[31] Parizzi, M.G., Sebastião, C.S., Viana, C.S., Pflueger, M.C., Campos, L.C., Cajazeiro, J.M.D., Tomich, R.S., Guimarães, R.N., Abreu, M.L., Sobreira, F.G. and Reis, R. (2010) Correlations between Rainfall and Mass Movements in the City of Belo Horizonte, MG. Geografias, 6, 49-68. (In Portuguese)

[32] Fisch, G., Vendrame, I.F. and Hanaoka, P.C.M. (2007) Rainfall Space Variability during the LBA/TRMM Experiment 1999 in Amazônia. Acta Amazonica, 37, 583-590. (In Portuguese) http://dx.doi.org/10.1590/S0044-59672007000400013

[33] Santoro, J., Mendes, R.M., Pressinotti, M.M.N. and Manoel, G.R. (2010) Correlation between Rainfall and Landslides Occurred during the Operation of the Prevention Plan of Civil Defense in State of São Paulo, SP. Proceedings of the 7th Brazilian Symposium on Geotechnical and Geoenvironmental Cartography, Maringá, 1-15. (In Portuguese)

[34] Mendes, R.M., Marinho, F.A.M. and Orlando, P.G. (2006) Geotechnical Properties of Unsaturated Residual Soils of the Serra do Mar. Proceedings of the 13th Brazilian Congress of Soil Mechanics and Geotechnical Engineering, Curitiba. (In Portuguese)

[35] Silva, P.C.F., Mendes, R.M., Nery, T.D. and Silva, I.C. (2007) Spatial Analysis of Geotechnical Properties of the Soils of Ubatuba by Local Deterministic Modeling and Geostatistics. Proceedings of the 6th Brazilian Symposium on Geotechnical and Geoenvironmental Cartography, Uberlândia-MG, ABGE, 309-323. (In Portuguese)

[36] Mendes, R.M., Marinho, F.A.M. and Prado, R.L. (2008) Use of the GPR Method for the Monitoring of the Moisture on Slopes. Proceedings of the 14th Brazilian Congress of Soil Mechanics and Geotechnical Engineering, Búzios. (In Portuguese)

[37] Mendes, R.M. and Marinho, F.A.M. (2008) Evaluation of a Residual Soil Profile of the Serra do Mar by Porosimetry. Proceedings of the 12th Brazilian Congress of Engineering Geology and Environmental, Porto de Galinhas. (In Portuguese)

[38] Mendes, R.M. (2008) Study of the Geotechnical Properties of Unsaturated Residual Soils of Ubatuba (SP). Doctoral Thesis, Polytechnic School, Sao Paulo University, Sao Paulo, 255 p. http://www.teses.usp.br (In Portuguese)

[39] Lima Junior, S.B., Prado, R.L. and Mendes, R.M. (2006) The Use of the Rayleigh Waves for in Situ Estimates of the Wave Velocities of Unsaturated Soils in Areas Subject to Mass Movements. Proceedings of the 2nd Brazilian Symposium on Geophysics, Natal, 1-10. (In Portuguese)

[40] Prado, R.L., Mendes, R.M. and Marinho, F.A.M. (2007) Estimates of Soil Moisture Content Using the GPR Method on Landslide Area in Ubatuba/SP. Proceedings of the 10th International Congress of the Brazilian Geophysical Society, Rio de Janeiro, 19-22 November 2007. (In Portuguese)

[41] Mendes, R.M., Marinho, F.A.M. and Funari, A.H. (2007) Evaluation of Granular Matrix Sensor (GMS) for Measuring the Suction. Proceedings of the 6th Brazilian Symposium of Unsaturated Soil, Salvador, 1-3 November 2007. (In Portuguese)

[42] Barbosa, E.E.M., Prado, R.L., Marinho, F.A.M., Oliveira, O.M. and Mendes, R.M. (2008) Evaluation of GPR Method to Estimate the Moisture Content of Sediments in Controlled Test. Proceedings of the 3rd Brazilian Symposium on Geophysics, Belém, 1-5. (In Portuguese)

[43] Barbosa, E.E.M., Prado, R.L., Mendes, R.M. and Marinho, F.A.M. (2010) Estimation of Moisture Content Using the GPR Method: A Comparative Evaluation in Laboratory and Field Experiments. Brazilian Journal of Geophysics, 28, 691-701. (In Portuguese)

[44] Vargas, M. (1999) Historical and Conceptual Review of the Landslides of the Serra do Mar. Soil and Rocks, 22 , 53-83. (In Portuguese)

[45] DAEE/Department of Water and Electric Power of the State of Sao Paulo (2013) Rainfall Database of the State of Sao Paulo (Brazil). Open Access Publisher. http://www.sigrh.sp.gov.br/cgi-bin/bdhm.exe/plu

[46] Modenesi-Gauttieri, M.C., Toledo, M.C.M., Hiruma, S.T., Taioli, F. and Shimada, H. (2011) Deep Weathering and Landscape Evolution in a Tropical Plateau. Catena (Cremlingen), 85, 221-230.

[47] Ahrendt, A. and Zuquette, L.V. (2003) Triggering Factors of Landslides in Campos do Jordão City, Brazil. Bulletin of Engineering Geology and the Environment, 62, 231-244. http://dx.doi.org/10.1007/s10064-003-0191-8

[48] Ahrendt, A. (2005) Gravitational Mass Movements-Proposal of a Forecast System: Application at the Urban Area of Campos do Jordão City-SP—Brazil. Doctoral Thesis, School of Engineering of São Carlos, São Paulo University, São Carlos, 390 p. (In Portuguese) http://www.teses.usp.br

[49] Heilbron, M., Pedrosa-Soares, A.C., Neto, M.C.C., Silva, L.C., Trouw, R.A.J. and Janasi, V.A. (2004) Mantiqueira Province. In: Geology of the Sul-American Continent: Evolution and Work of Fernando Flávio Marques de Almeida, 203-236. (In Portuguese)

[50] Hasui, Y., Mioto, J.A. and Morales, N. (1994) Geology of the Pré-Cambriano. In: Falconi, F.F. and Negro Jr., A., Eds., Soils of the Coast of Sao Paulo, ABMS, Sao Paulo, 41-68. (In Portuguese) 
[51] Morais, S.M., Rodrigues, J.B., Sachsi, L.L.B. and Dehler, N.M. (1999) Integrating the Geological Map of Santos 1:250.000, State of Sao Paulo (Brazil). Ministério de Minas e Energia—CPRM, Serviço Geológico do Brasil. (In Portuguese)

[52] Wolle, C.M. (1985) Peculiarities of "in Situ” Behavior of Tropical Soils: Slope Stability. Committee on Tropical Soils. Proceedings of the 1st International Conference on Geomechanics in Tropical Lateritic and Saprolitic Soils, Brasília, Progress Report. t.3.2, 51 p. (Discussion)

[53] Wolle, C.M., Guidicini, G., Araujo, J.S. and Pedrosa, A. (1978) A Slide Mechanism in the Slopes of the Serra do Mar Southern Brazil. Proceedings of the 3rd International Conference of Engineering Geology, Madrid, 4-8 September 1978, $14 \mathrm{p}$.

[54] CEDEC/Coordination of Civil Defense of the State of Sao Paulo (2013) Preventive Plan of Civil Defense-PPDC: Database 2012/2013. http://www.defesacivil.sp.gov.br/v2010/portal_defesacivil/index.asp

[55] INPE/National Institute of Spatial Research (2014) Integrated System of Environmental Data/SINDA-Data of Automatic Environmental Stations_-PESM Picinguaba/Ubatuba (SP). http://sinda.crn2.inpe.br/PCD/

[56] Habibagahi, K. (1973) Temperature Effect and the Concept of Effective Void Ratio. Indian Geotechnical Journal, 7, 14-34. 